\title{
Las constituciones del hospital de Santa Cruz (Toledo)
}

\author{
laura Santolaya Heredero *
}

Fue fundado dicho hospital en la ciudad de Toledo en 1499 por el arzobispo don Pedro González de Mendoza, conocido por el "Gran Cardenal de España". Sixto Ramón Parro relata al respecto: "Hacia los últimos años de su pontificado (el del cardenal Mendoza) tuvo el laudable pensamiento de fundar una casa "para recoger, criar y educar los niños expósitos", muchos de los cuales perecian, por falta de un establecimiento de esta clase, victimas del criminal abandono de sus padres. Para ello impetró y obtuvo en $1 .^{\circ}$ de octubre de 1494 la Bula conducente del papa Alejandro VI, concertó con el Cabildo que le cediese un terreno que había inmediato a la catedral, y encargó al maestro mayor la misma, el famoso Enrique Egas, la formación y trazas para el edificio, pero cuando todavía no estaba definitivamente arreglado nada, ocurrió su fallecimiento a principios de enero de 1495. Mas no olvidó en su testamento la idea del hospital, antes bien, rogó con mucho ahínco a la Reina Católica, su albacea, y a sus inmediatos parientes los duques del Infantado, que llevasen a cabo su proyecto sin alzar mano, dejando para realizarlo cuantiosas sumas, y declarando por su universal heredero al hospital, que percibió de esta herencia más de 75.000 ducados (1.555.000 rs.)" " .

Hubo algunos inconvenientes para la elección del solar que, finalmente, fueron superados: “... y ya no quedaba más inconveniente por vencer que el de la definitiva elección de terreno donde erigir el magnífico monumento proyectado por el célebre Egas, aprobado en vida por el fundador y aceptado después por la augusta testamentaría y familia consanguínea del Prelado, que por su eminente devoción a la Santa Cruz, cuyo título cardenalicio llevaba, quiso fuese ésta la advocación de tan

* Profesora de Historia Moderna. UNED.

' PARRo, S. R., Toledo en la mano, vol. II, 1857. Ed. Facsímil, 1978, págs. 414-415. 
insigne establecimiento, como lo fue también del Colegio Mayor de Valladolid que igualmente había fundado. Ocurrió, pues, que por entonces quedó desocupada la parte central de los antiguos palacios de Galiana que hasta aquella época habian tenido las monjas benedictinas de San Pedro de las Dueñas (...), las cuales, unidas ya con las Concepcionistas, que acababa de fundar la dama doña Beatriz de Silva, fueron a habitar el convento que dejaban vacío los religiosos de San Francisco al trasladarse al famoso monasterio de San Juan de los Reyes; y doña Isabel escogió este local para levantar en él la suntuosa fábrica del hospital de Santa Cruz o de niños expósitos" ?.

Merece la pena transcribir lo que Parro decía de dicho edificio:

«Este edificio es uno de los primeros que en España se construyeron al gusto que llamamos plateresco, y que no es otra casa que una combinación de la arquitectura gótica con la del renacimiento, que iba resucitando las formas de la greco-romana, pero sin abandonar del todo los ornatos graciosos antiguos que fueron refinándose hasta producir las más exquisitas preciosidades. Tardóse en construirle diez años, desde 1504 hasta 1514, bajo la dirección del mencionado arquitecto autor de los planos, Enrique Egas, empleando en toda la fábrica, interior y exteriormente, la más sólida cantería, excepto en la fachada principal o de Mediodía, que es de sillares cortados con adornos de piedra blanca; las maderas son de lo mejor de la serrania de Cuenca y fueron las primeras que se condujeron por el río Tajo, pues hasta entonces no se habia empleado este sencillo y económico recurso. Ocupa esta gran mole una superficie de más de 500 pies de largo, incluso el descubierto o corral que tienen a su espalda, por 300 y pico de ancha, resultando su planta cuadrilonga, con dos pisos sumamente altos, aparte del embovedado general y del entresuelo que se agrega en toda la línea de Oriente por el desnivel de terreno que es alli más bajo. Tiene cuatro patios, dos de ellos magníficos (...), y en el centro de todos está la Iglesia en forma de cruz griega, o sea, de cuatro brazos iguales, pues tal fue la devoción del cardenal fundador a este sagrado signo de nuestra redención que en todas sus cosas le usaba, y quiso que las plantas de este edificio y del Colegio Mayor de Valladolid, que también es fundación suya, tuviese esta figura y llevasen el título de Santa Cruz" ${ }^{3}$.

El hospital estaba dedicado solamente a recoger y criar niños expósitos "sin otro destino" lo que le distanciaba del propio concepto de

\footnotetext{
2 Parro, S. R., obra citada, vol II, págs. 415-416.

3 PaRro, obra citada, vol. Il, págs. 416-418.
} 
«hospital» en la Edad Moderna, entendido como esa combinación de clínica y asilo que proporcionaba curación a los pobres enfermos y asistencia a los necesitados. Es posible que hubiera muy pocos como él en la Corona de Castilla. El mismo Hospital Real de Santiago acogió a expósitos ya en el siglo XVIII, dentro de la atención general de los gobiernos ilustrados por este problema, y así otros muchos ${ }^{4}$. Pero la institución, como tal, resultaba peculiar en la primera década del siglo XVI; quizá el antecesor inmediato, y del que pudo tomar don Pedro de Mendoza la idea, fue don Francisco Ortiz, canónigo toledano, arcediano de Briviesca y notable "coleccionista" de beneficios eclesiásticos, que en el ocaso de su vida decidió invertir sus bienes en una fundación benéfica que fuera distinta de las habituales; y así comenzó a construir en 1483, "en las propias casas de su morada que es donde hoy están", un edificio para recoger y tratar a treinta y tres dementes y albergar también a trece niños expósitos "que las madres desamparaban, carescientes (éstas) de la razón natural que los animales brutos usan con sus hijos" ${ }^{5}$. Luego, estos niños fueron sustituidos por "donados" que desempeñaban los oficios subalternos del hospital cuando se acabó de construir el de Santa Cruz.

A mitad del siglo XVIII, cuando se hizo el recuento del Catastro de Ensenada, 363 niños y niñas dependian del hospital, aunque la gran mayoría estaba al cuidado de familias particulares. Éstas, por lo que se puede comprobar en el vecindario, eran de clase baja que percibian una paga por la atención de aquéllos. No puede saberse, a ciencia cierta, cuántos niños y niñas eran criados por amas de cria dentro del mismo hospital ni cuántos se estaban educando. La política que llevaba el hospital era la de recibir a los niños y asignarlos luego a amas de fuera; en la Constitución XI se decía: "Conforme se vayan echando niños a este hospital, reservando los dos de menos edad para la sala, todos los demás se han de ir dando a criar a amas de fuera...", añadiéndose una prevención para evitar que los niños volvieran al poder de sus madres naturales: «por lo que regularmente se ha de observar que los niños que se echaren en el torno del hospital, en el ámbito de la Santa Iglesia o en alguna otra parte dentro de Toledo, se den a criar con amas de los lugares; y los que trajeren de los lugares se pongan con amas de Toledo...". Luego, acabado el tiempo de crianza, eran devueltos al hospital $y$ en él permanecían hasta que fueran aceptados por familias: las niñas, para ayudar a la casa y servir, y los niños como aprendices de algún oficio.

${ }^{4}$ Ver Garcia Guerra, Delfin, El Hospital Real de Santiago (1499-1804). Santiago 1983, pág. 315 .

${ }_{5}^{5}$ Porres, Julio, Historia de las calles de Toledo, vol. II. Toledo 1982, pág. 894. 
El citado Catastro de Ensenada indicaba: «los niños expósitos que actualmente sostiene y cría dicha casa-hospital son: dos niños de pecho con dos amas en ella, y fuera y repartidos en amas, doscientos cuatro; y en diferentes lugares tiene dados a criar hasta el número de trescientos treinta y nueve de ambos sexos. $Y$ asi mismo tiene dicho hospital veinticuatro niñas, hijas de la casa, educadas de doctrina y maestra, las que suelen acomodarse a servir, y si se despiden vuelven a él hasta nuevo acomodo" ${ }^{6}$.

La renta de Santa Cruz, aun siendo la más elevada de los hospitales de la ciudad, en el tiempo a que estamos haciendo referencia apenas era suficiente; tenía poca participación en los diezmos y en total sumaba 68.908 rs. anuales provenientes en su mayor parte de 16 juros (53.882 rs.) y de una dehesa en el término de Toledo, "Pinedo", de 942 fanegas de 500 estadales que daba un producto bruto de 11.618 rs. ?

Era patrono del hospital el Cabildo Catedral, quien anualmente en uno de los días de la octava de la Invención de la Santa Cruz, se trasladaba a aquél en procesión para hacer "solemnes honras al cardenal». "La entrada de las nodrizas y expósitos en el coro, podía ser como una especie de revista a que se presentaban pública y solemnemente los niños y las encargadas de su alimentación ante el Cabildo patrono, sin perjuicio de que había sus visitadores que examinaban de continuo el estado del hospital y su administración, para remediar instántaneamente todo abuso" ${ }^{8}$.

Podria decirse que en el siglo XVIII el aparato institucional de Santa Cruz aparecia como modélico; por lo menos, la organización que reflejan sus Constituciones donde nada se deja al azar. Cierto es que el quehacer diario podria dar origen a abusos. $Y$ de hecho, una $R$. Cédula de Carlos III intentó solucionar los malos métodos que se habían ido infiltrando a través de los tiempos: «... con que desde los pueblos son conducidos a dicho hospital los más de los niños, que comúnmente encargan y fían su conducción a personas que, por su corta edad, poco talento o pobreza, no los trataban en los caminos con aquella caridad y cuidado que se necesitaba, ni los preservaban de las inclemencias y rigores del tiempo, como tampoco cuidaban de que se les diese el aliento necesario, así llegaban en todas las estaciones del año, y con el mayor desabrigo, puestos muchos de ellos en alguna espuerta, casi enteramente desnu-

\footnotetext{
${ }^{6}$ Archivo Provincial de Toledo. Catastro de Ensenada, libro 689.

7 Santolaya, Laura, Una ciudad del Antiguo Régimen: Toledo en el siglo XVIII. Tesis doctoral inédita, UNED, septiembre 1989.

${ }^{B}$ PARRO, obra citada, vol. II, pág. 430.
} 
dos, como la cosa más despreciable. Que de aquí provenía el que no pocos de ellos, al tiempo de recibirse en el hospital, se hallaban tan maltratados, que fallecian luego y otros con alguna impresión en la cabeza, brazos u otra parte del cuerpo que les hacía inútiles para toda la vida; otros, tan penetrados del hambre, calor o frío que no tienen robustez para cosa alguna, no sirviendo el reconvenir sobre ello a los conductores, porque éstos se disculpan con que así se los entregaron, sucediendo lo mismo si les pedían los papeles o certificaciones de si estaban bautizados los niños, y demás que convenía, para hacer en los libros del hospital los asientos correspondientes y dar las providencias necesarias".

Las Constituciones que transcribimos aquí, todavía inéditas, son las procedentes de la reforma de las primitivas hechas en 1739 y fueron las que permanecieron hasta el siglo XIX cuando con la desamortización, 1847, fue cedido el edificio como bien nacional por la Junta de Beneficencia y el Ayuntamiento al Colegio General Militar en tanto que la casa inclusa se trasladaba al ex-convento de San Pedro Mártir. 
CONSTITUCIONES PARA EL GOBIERNO DEL HOSPITAL DE NINOOS EXPÓSITOS, QUE CON EL TITULO DE SANTA CRUZ FUNDÓ EN LA CIUDAD DE TOLEDO EL EMINENTISIMO SEÑOR DON PEDRO GONZÁLEZ DE MENDOZA, CARDENAL ARZOBISPO DE TOLEDO, PRIMADO DE LAS ESPAÑAS, HECHAS $Y$ ORDENADAS CONFORME A LAS NUEVAS PROVIDENCIAS QUE EN ATENCIÓN AL ESTADO PRESENTE DE LAS RENTAS DE DICHO HOSPITAL SE ACORDARON POR SU ÚNICO PATRON AL ILUSTRISIMO SEÑOR DEÁN Y CABILDO DE LA SANTA IGLESIA PRIMADA, EN EL DÍA 25 DE JUNIO DE 1739 AÑOS

(Archivo Municipal de Toledo)

Constitución primera.

Del oficio de administrador y sus obligaciones.

El administrador que nombrare el ilustrísimo señor deán y cabildo ha de venir a morar al Hospital el último día del mes de agosto siguiente a su nombramiento; se ha de entregar de las Constituciones del Hospital, y de los tres libros que sirven a su gobierno; los que según se acostumbra, le dejará prevenidos el administrador que saliere. Ha de tener de su cuidado y obligación velar continuamente sobre todo el gobierno económico espiritual y temporal del dicho Hospital: procurando con la mayor atención y diligencia que asi los capellanes, como el visitador, sacristán, ama mayor, maestro de niños, maestra de niñas y demás ministros, cumplan exactamente sus obligaciones: haciendo que estén bien instruidos en ellas, según y como se contienen en estas Constituciones. Ha de reconocer todos los niños que se echen al Hospital, antes que se entreguen a las amas de afuera; y siempre que se echaren a hora competente, los ha de hacer traer a su presencia, primero que los lleven a la sala. Ha de escribir por sí, y cuando no pudiere por persona de toda satisfacción, las partidas de entradas y salidas de los niños, y las de bautismo. Ha de atender mucho a que los niños, asi de pecho como de destete, estén bien asistidos, y que los grandes, que no tuvieren paga, estén lo más bien acomodados que fuere posible: providenciando con caridad y discreción cuanto conviniere al mayor bien de los hijos de este Hospital, no sólo de chicos que tuvieren paga sino de los grandes, que no hubieren tomado estado. Ha de pagar por tercios ya cumplidos los salarios señalados a las amas y ministros: $y$ las raciones las ha de pagar por semanas, una anticipada: excepto el pan, pues éste a los que le tengan señalado, ha de hacer que se les dé cada día. El dinero que fuere necesario, le tomará el receptor del Hospital, dando recibo: y la cuenta de todo lo que recibiere y gastare la ha de 
dar al cabildo, luego que cumpla el tiempo de su administración o antes, si el cabildo lo mandare. Dentro del primero mes de su administración ha de visitar la iglesia y sacristía, y dos meses antes de cumplir la administración ha de hacer otra tal visita. Su salario ha de ser trescientos ducados largos en cada un año, casa y agua del algibe.

Constitución $/ 1$.

De los niños que se han de recibir en este hospital.

Todos los niños expósitos que fueren desamparados de sus padres y madres por pobreza o por otras causas se han de recibir en este Hospital, porque asi lo dejó expresamente ordenado en su testamento el eminentísimo señor don Pedro González de Mendoza, fundador. Si el niño fuere traído a este Hospital por el portero de la santa iglesia, o porque le halló en la piedra, que alli está puesta con ese fin o porque le encontró en alguna parte del ámbito, se le han de dar del caudal del Hospital ocho maravedis por cada niño que trajere: los niños que trajeren al Hospital hallados en Toledo fuera de la santa iglesia o en alguno de los lugares del contorno de esta ciudad dentro de las cinco leguas, o aunque sean de muy lejos, los trajeren por camino, que llaman vía ordinaria, transitando de lugar en lugar con certificación de los curas o de las justicias, se han de recibir francamente, pero sin dar nada a la persona que los traiga. Si de alguna ciudad, villa o lugar fuera de las cinco leguas del contorno de Toledo, enviaren algún niño expósito con orden del cura o de la justicia, y pidieren recibo del niño, han de dar cuatro ducados de limosna para el Hospital; y menos, no dará el administrador recibo del niño, ni consentirá que, de mano de la persona que le traiga, se reciba aquel niño en la sala; pero si le expusieren en el torno de la portería se recibirá, como los demás, que allí se exponen: en dando los cuatro ducados a la persona que los entregue, dará el administrador recibo de ellos, y del niño, expresando en el recibo las señas más notables que el niño tuviere, y el nombre de la persona que le traiga. Por ningún caso se ha de indagar quiénes sean los padres de los niños que echaren en este Hospital; y si, por casualidad, lo supiere el aministrador, la ama mayor o cualquier otro ministro del Hospital , se ha de tener en secreto.

Constitución III.

Del modo de asentar las partidas de recepciones de los niños que se echaren a este hospital.

Luego que se traiga algún niño a este Hospital le tomará el portero, y presentándosele primero al administrador (si fuere hora competente) inmediatamente 
le llevará a la sala de los niños, y se le entregará al ama mayor: quien después de haberle envuelto y proveído de lo necesario, subirá lo más presto que pueda al cuarto del administrador para que se asiente aquel niño en el libro llamado "Despensa menor»: y el administrador a vista del ama mayor escribirá la partida, empezándola por el día, mes y año en que el niño fuere echado, después pondrá la edad que el niño tuviere, a juicio del ama mayor: luego escribirá con toda puntualidad las envolturas con que echaron al niño, según y como fueren, expresando su calidad y colores: se pondrán las señas más notables que el niño tuviere, y se copiará a la letra en la misma partida cualquier papel, que con el niño se hallase; y si la persona que le trajere asegurase ser aquel niño hermano de alguno de los ya recibidos en el Hospital, se anotará en esta partida, y en la que dijere ser su hermano.

Constitución IV.

Del bautismo de los niños.

Cuantos niños se echaren a este Hospital se han de bautizar debajo de condición, aunque traigan cédula, que diga estar bautizados, si no es que la cédula viniere firmada de algún cura o persona conocida, que haga fe, pues entonces asegurándose el administrador ser la firma del sujeto que en ella se nombre, se sentará a lo que la cédula dijere: Si al tiempo de echarse el niño reconociere el ama mayor que viene entelerido y temiere que vivirá poco, le llevará al instante al capellán semanero para que le bautice; y si la pareciere que está el niño tan a los últimos de su vida, que ni para llevarle el capellán semanero habrá lugar, la misma ama mayor le bautizará por sí: para lo cual deberá estar instruida en la forma y modo de bautizar: cuando los niños que se echaren estuvieren robustos, de modo que no aparezca riesgo alguno de que se mueran presto, se detendrán en la sala, y al dia siguiente, $o$ antes si se pudiere, las amas de pecho, ahora competente, los llevarán a bautizar a la capilla parroquial de San Pedro, sita en la santa iglesia, llevando siempre la cédula del administrador para el cura o teniente de San Pedro: en la cual cédula se ha de expresar el nombre que se le haya de bautizar, o bien "sub conditione", cuando al administrador no le constare que está bautizado (como es regular) o bien absolutamente, si el administrador estuviere cierto de que no tiene agua de bautismo (que podrá suceder rara vez) o bien previniendo que ya tiene agua de bautismo, si el administrador estuviere cierto de ello. En caso de que se eche algún niño, que conste al administrador estar ya bautizado solemnemente, no habrá que hacer sino solicitar el administrador se traiga la fe de bautismo del cura o teniente de la parroquia a donde estuviere bautizado. 
Constitución $V$.

De los nombres que se han de poner a los niños en el bautismo.

Los nombres que se han de poner a los niños de este Hospital, que se bautizaren en la capilla de San Pedro, se han de señalar por el administrador, quien en esta parte ha de observar que a ningún niño se le ponga el nombre que diga la cédula que echaren con el niño, sino otro diferente, y ha de atender a que los niños, que se bautizaren en su trienio, se les pongan nombres distintos: si a los bautizados, en caso de necesidad por los capellanes del Hospital o por el ama mayor, se les pusieren nombre, que ya tenga otro de los niños de aquel trienio, el administrador le añadirá un segundo nombre con que aquel niño quede bien distinguido de todos los de su tiempo. En cuanto a los apellidos (que también han de ser a arbitrio del administrador) se procederá con la misma atención de que sean bien diversos.

Constitución VI.

Del modo de asentar las partidas de bautismo.

Las partidas de bautismo de todos los niños que se echaren a este Hospital se han de asentar en las márgenes de las partidas de sus recepciones, expresando en ellas el nombre y apellido del niño, y la parroquia, día, mes y año en que se hubiere bautizado; y para que en esto no pueda haber olvido, se observará que la cédula del administrador (que las amas de pecho han de llevar a la capilla de San Pedro, siempre que vayan a bautizar) la vuelvan firmada del cura, o teniente, que administrare el baurismo; así firmada, la entregarán las amas de pecho al ama mayor, y ésta, lo más presto que pueda, la llevará al administrador, quien luego que reciba la cédula, conforme a ella, sentará la partida de bautismo en el lugar y forma a que arriba se expresa. Si se echare al Hospital algún niño, que le conste al administrador estar ya bautizado solemnemente, traída la fe de bautismo (como se previene en la Constitución IV), lo que de ella constare se anotará en el lugar correspondiente.

Constitución VII.

Del oficio de ama mayor y de sus obligaciones.

La ama mayor (que nombrará el administrador por el tiempo de su voluntad) ha de ser mujer de modo viuda y que haya tenido hijos: ha de habitar en la sala de los niños y no ha de tener en su compañía hijo alguno varón. Se ha de 
entregar por inventario de toda la ropa y ajuar, que hubiere en la sala de los niños, y ha de responder de ello. Ha de nombrar las dos amas de pecho, que continuamente ha de haber en la sala de los niños, y las ha de mudar cuando la parezca conveniente. Se ha de entregar de todos los niños, que se echaren al Hospital, luego que los echen, y la primera diligencia ha de ser reconocer con todo cuidado si vienen enfermos, de modo que inste la necesidad de bautizarlos; y si la pareciere que insta hará al punto que se bauticen, según se previene en la Constitución IV. Ha de envolver por la primera vez a los niños con envolturas del Hospital: examinando atentamente, al tiempo de envolverlos, las envolturas y señas notables que los niños trajeren, encomendándolas a la memoria, para dar de ellas puntual noticia al administrador: lo que fuere de provecho en las envolturas con que echaren los niños, lo lavará y reservará para envolver a otros: envolviendo los niños ella misma, los dará el papero y los proveerá de lo que necesitaren: así envueltos y proveídos, los entregará al ama de pecho, que los haya de criar en la sala, interim que se despachen con más de fuera: luego subirá a dar cuenta al administrador del niño que se hubiere echado para que le asiente en el libro, según y como se previene en la Constitución III. Ha de poner toda la atención y esmero en que los niños de pecho, que hubiere en la sala, estén bien cuidados y con toda limpieza, y el papero que se les haya de dar le ha de hacer siempre por su mano. Ha de inquirir continuamente de todos los niños, así de pecho como de destete, que se crien fuera del Hospital, si están bien asistidos; y si se supiere que alguno no lo está, ha de dar cuenta al administrador, para que se le ponga otra ama: ha de solicitar que las muchachas, que hubieren cumplido el destete y las de la labor que hubieren los doce años, se pongan a servir en buenas casas, y siempre con noticia y aprobación del administrador. Ha de informarse, por los medios que pueda, de las amas que vinieren por niños, si son a propósito, porque su informe ha de ser el que principalmente gobierne para despachar los niños afuera: y cuando falten amas, ha de poner toda la diligencia que pudiere en buscarlas. Ha de asistir al despacho del administrador todos los días, a las horas que el administrador la señalare. Ha de ser también de su obligación dar de comer a las niñas de la labor y a las demás muchachas que hubiere en la sala, entregándose por semanas la ración, que está señalada a cada una y repartiéndosela en almuerzo, comida y cena caliente, según se viene practicando; y a las niñas del número las dará un poco de pan por la tarde: la comida se la ha de dar todos los dias luego que den las doce, y la cena en tiempo de invierno luego que den las ocho, y en verano luego que se acabe el rosario y la doctrina. También se ha de entregar del carbón, aceite, jabón, pan para los paperos, y del dinero señalado para miel, sal, alhucema, vidriado y sogas, en las porciones y cantidades que se expresan en el libro de despensa mayor, y todo lo ha de gastar en sus destinos con buena economia: observando que del carbón señalado para la cocina de la sala de los niños, ha de dar desde el día quince de noviembre hasta el día veinticinco de marzo, un brasero a la mañana y otro a la tarde para la sala de la labor: y asimismo ha de dar ascuas los sábados por la tarde para enjugar, cuando fuere menester, la ropa blanca de las niñas de la labor. Ha de cuidar de que las niñas del número, y de más muchachas que hubiere en la sala, estén proveídas de lo necesario para su 
vestido y calzado: y de lo que las faltare ha de dar cuenta al administrador, para que con su orden se las provea. Si las muchachas ganaren algo con sus labores, se entregará de ello, y se lo empleará en lo que cada una más necesite, sin que lo que gane una, se lo aplique a otra. Con el jabón que da el Hospital ha de hacer que se lave la ropa blanca de los niños que hubiere en la sala, la suya, la de la maestra, y la de las muchachas, asi del dinero como supernumerarias: disponiendo que las amas de pecho laven su ropa y la de los niños, y que la demás ropa la laven las muchachas grandes, que mejor lo sepan hacer. Ha de cuidar de que las niñas de la labor y demás muchachas, que hubiere en la sala, se muden ropa blanca los domingos. Ha de coser y remendar toda la ropa, que sirviese a los niños de pecho, y la que haya de servir a todas las muchachas y muchachos que hubieren en el Hospital, hará que se cosa, y que se remiende en la sala de la labor, entregándosela a la maestra. En lavar, guisar, fregar, barrer y demás haciendas, que se ofrezcan dentro de la sala de los niños, ha de ocupar a las muchachas del número y supernumerarias, que valgan para ello; y luego que acaben las haciendas, las mandará que se vuelvan a la sala de la labor. Ha de cuidar y guardar la ropa blanca y de vestir, que sirviere a las muchachas, que no sean del número. Su salario ha de ser veintiséis reales al mes, pagados por tercios, y su ración una libra de carnero, un pan, y diez maravedís cada dia, médico, cirujano, botica, casa y agua del algibe.

\section{Constitución VIII.}

De las amas de pecho que ha de haber en la sala de los niños.

Para que los niños, que se echen a este Hospital, tengan quien prontamente los dé de mamar, ha de haber continuamente en la sala de los niños dos amas de pecho, las cuales han de elegir y mudar a su discreción la ama mayor: estas dos amas de pecho, las cuales ha de elegir, y mudar a sus discreción la ama mayor. Estas dos amas han de ser mozas, señaladamente robustas, que tengan buena leche, de natural pacífico y que hayan concebido de legitimo matrimonio: han de tener su habitación dentro de la sala de los niños, en el cuarto a donde está la cuna, y a la orden del ama mayor han de criar los niños de pecho que hubiere en la sala, con el mayor cuidado: han de lavar la ropa de los niños y la suya. La ama mayor ha de cautelar que estas dos amas no comercien con sus maridos mientras estuvieren en la sala. Su salario ha de ser veinte reales cada dia, con más la lumbre y sal que necesitaren para guisar la comida. Y se la ha de dar cama separada a cada una con ropa del Hospital.

\section{Constitución IX}

De las amas que han de criar niños de pecho fuera del hospital.

Las amas, que hayan de criar los niños de pecho fuera del Hospital, han de ser de buena fama y costumbres, que tengan buena leche, y no la den a medias, 
ni den de mamar calostros, que tengan casa en Toledo o en alguno de los lugares del contorno, y que no sean muy pobres: adquirir estas noticias, y certificarse de ellas en el modo posible, principalmente ha de correr al cuidado de la ama mayor, quien con el frecuente trato, que forzosamente ha de tener con todas las mujeres que crien niños de este hospital, podrá más fácilmente tomar estos informes: $y$ porque de las mujeres, que vivan fuera de Toledo, será más dificultoso averiguar sus calidades, cuidará el administrador, y la ama mayor de que no se dé a criar niño alguno fuera de Toledo, a mujer que no traiga certificación de abono del cura de su lugar. El salario de estas amas ha de ser de diez y ocho reales cada mes, y cada tercio una librea, que se compone de dos varas de cordellete y vara y medio de lienzo.

Constitución $X$.

De los niños de pecho que ha de haber en la sala.

Siempre en la sala de los niños ha de haber dos (a lo menos) de pecho, a los cuales darán de mamar las dos amas, que ha de haber de asiento, cada una al suyo, el que señalare la ama mayor: quien en cuanto a esto ha de regularmente guardar turno, alternando con las dos amas los niños, que fueren echando; pero si juzgase conveniente dar a una misma ama dos o más niños sucesivamente, así lo ha de hacer: estos dos niños, que ha de haber en la sala, han de ser los de menos edad; sino es que alguno viniere enfermo, o delicado, de modo que crea la ama mayor que convendrá detenerle en la sala, para que se refuerce, pues en ese caso le detendrá todo el tiempo, que fuere menester hasta que se recobre. Si se juntaren en la sala más niños que los dos, y no hubiere amas de fuera con quien prontamente despacharlos, interim que las haya se mantendrán en la sala hasta cuatro niños los más pequeños, dos con cada ama; y los que pasen de cuatro, se darán a criar a alguna mujer de dentro de Toledo, pagándola por dias o por noches lo menos que se pudiere concertar. En echando algún niño, que tenga mal pegajoso, como sarampión, viruelas, sarna u otro mal semejante, por ningún tiempo se le ha de tener en la sala, sino que a cualquier costa se le ha de despachar con ama de fuera; y si hecha la diligencia ni se hallare ama, que le lleve, la ama mayor dará cuenta al administrador, para que con consulta de médico tome las providencias convenientes, a fin que el niño se mantenga, sin riesgo de que su mal se pegue en la sala.

Constitución $X I$.

De los niños de pecho que se den a criar a amas de afuera.

Conforme se vayan echando niños a este Hospital, reservando los dos de menos edad para la sala, todos los demás se han de ir dando a criar a amas de 
afuera, que tengan las calidades prevenidas en la Constitución IX. Y porque importa mucho para el bien de los niños, que se acierte en la elección de sus amas de pecho, han de proceder en esto con el mayor cuidado, asi el administrador como el ama mayor: quien nunca ha de despachar niño alguno sin noticia y aprobación del administrador: ni las mismas amas de pecho, a quienes se entreguen los niños, los han de poder traspasar a otras sin expreso consentimiento del administrador, y anotándolo en el libro grande en su propio folio: observando inviolablemente no pagar el salario por el tiempo que duraren los traspasos, que voluntariamente hicieren las mismas amas: a quienes tampoco se ha de pagar el salario por cualquier tiempo, que se averigüe haber dado leche a medias. En el despacho de los niños se ha de atender mucho a que las amas los lleven, vivan en lugares apartados de aquellos en que se pueda sospechar que han nacido los niños, para evitar en todo lo posible la contingencia de que vuelvan los niños al poder de sus madres naturales: por lo que regularmente se ha de observar que los niños que se echaren en el torno del Hospital, en el ámbito de la santa iglesia o en alguna otra parte dentro de Toledo, se den a criar con amas de los lugares: y los que trajeren de los lugares se pongan con amas de Toledo: ocultando siempre de las amas, que los llevaren, la noticia de adonde se trajeron y del dia en que se echaron: en que la ama mayor ha de proceder con tal cautela que nunca los padres o madres de los niños puedan entender qué amas los crían. Si al administrador o a la ama mayor se preguntare por algún niño, sólo ha de responder si vive o no vive, lo demás se ha de tener en secreto: excepto cuando se pregunte por el niño, con el fin de sacarle del Hospital, que en tal caso se hará lo que previene la Constitución XIX. Si entendiere el administrador, - la ama mayor, que por parte del padre o madre de algún niño se ha llegado a saber el ama de cría, luego se ha de poner aquel niño con otra ama, que no pueda saberse.

Constitución XII.

Del tiempo que los niños han de mamar.

Aunque no se puede dar regla cierta en el tiempo en que los niños deberán de mamar, porque esto pende de que sean más o menos delicados; no obstante, siendo éste uno de los puntos que pide mayor consideración: porque si a los niños se les quita el pecho antes de tiempo, podrán perecer; y si se les da a mamar más de lo necesario, será de grave perjuicio a las rentas del Hospital; por tanto se ha de observar que a todos los niños se les dé de mamar regularmente diez y seis meses, nada menos: y si fuesen notablemente delicados, o estuviesen enfermos de calidad, que se haga juicio, que necesitan de mamar más tiempo, se les alargará el pecho todo el tiempo que fuere menester, a discreción del ama mayor: por cuyo dictamen se ha de gobernar siempre el administrador en esta parte; y si la ama mayor estuviese dudosa, hará que el admi- 
nistrador que se consulte al médico. El salario que se ha de dar a las amas por el tiempo de pecho se previene en la Constitución IX.

Constitución XIII.

Del tiempo de destetar los niños.

Por cuanto ha enseñado la experiencia ser de grave perjuicio que los niños apartados de las amas, que los han dado de mamar, inmediatamente que se les quita el pecho, pues juntándoseles el disgusto que sienten en la falta de leche, la natural tristeza de verse sin sus amas, se ha observado haberse muerto algunos, sin descubrirse otra causa que esta melancolia; y siendo por otra parte cierto que conviene las más de las veces no dejar los niños para el tiempo de su crianza en poder de la amas, que los han dado el pecho, porque comúnmente tienen hijos propios, y son cada día más pobres: para evitar en lo posible uno y otro inconveniente, se observará de aqui en adelante, que cumplidos los dieciséis meses de lactación, se mantengan los niños otros cuatro meses en poder de las amas que los han dado de mamar, con el nombre y paga de medio pecho: en los cuales cuatro meses han de cuidar las amas de irlos destetando poco a poco; y asi se conseguirá que libres ya de las desazones, que padecen en el destete, y aigo más robustos, haya más comodidad de ponerlos en casas mejores, para los años que les dure la paga de destete, que es el tiempo que más influye en su crianza. El salario que se ha de dar a las amas por estos cuatro meses de medio pecho, ha de ser de nueve reales por cada mes y una librea por los cuatro.

\section{Constitución XIV.}

De los niños de destete.

Cumplido que sea el tiempo del pecho y medio pecho, se han de mantener los niños con el nombre y paga de destete, o en poder de las amas que les dieren de mamar, o en poder de otras, las que al administrador, con informe de la ama mayor, parezca más a propósito: teniendo en esto atención tanto a que los niños, para el tiempo del destete, no queden con amas que por si tengan muchos hijos, ni del Hospital, arriba dos: cuanto a que no sean personas que mendiguen, ni tengan oficios muy viles: y porque es muy regular que los que crian estos niños, en los años que los dura la paga de destete, se quieren quedar con ellos para siempre, ha de atender mucho el administrador a que los varones se pongan desde luego en casas de oficiales de buenos oficios, que se los puedan enseñar; y las niñas en poder de mujeres recatadas y de gobierno que las tengan en buena crianza y honestidad, como se previene en la Constitución XXIV 
de las antiguas: a las amas, que tengan estos niños de destete, se les ha de dar seis reales cada mes y una librea cada tercio.

\section{Constitución $X V$.}

Del tiempo que ha de durar la paga del destete.

Con la paga de destete se han de mantener todos los niños de este Hospital, desde que cumplan el tiempo de pecho y medio pecho, hasta que tengan siete años cumplidos; y si habiendo cumplido los siete años, estuviere algún niño más desmedrado, notablemente, de lo que corresponde a su edad podrá el administrador, a su discreción alargarle la paga algún tercio o tercios, con tal que no pase de un año: y lo mismo podrá hacer siempre que juzgue conveniente alargar esta paga de destete un año más, o para excusar gasto al Hospital o para que el niño quede más bien acomodado.

Constitución XVI.

Del modo de despachar los niños de pecho y destete con amas de afuera.

Cuando hubiere de despachar algún niño con ama de afuera, pasará la ama mayor acompañada de la mujer, que quiera llevar el niño, a dar cuenta al administrador; quien asegurado de tener aquella ama las calidades que se requieren en la Constitución IX, sentará en el libro grande al folio conveniente, primero el nombre y apellido del niño, luego su edad, la que constare de la partida de su recepción, después el nombre y el apellido de la ama, que le hubiere de llevar, con más el nombre y apellido de su marido, o sea vivo o sea difunto; y si viviere en Toledo, la parroquia. Si el niño fuere de pecho, le ha de envolver la ama que le llevare en envolturas suyas, y se la han de dar por primera vez la mitad del salario de un mes y una librea adelantada; si fuere de destete, se le llevará la ropa que tuviere, y se la adelantará el salario de un mes y una librea: poniendo a la margen izquierda de la partida el número de la librea y a la derecha el número de los reales que se la dieren, y cerrando la partida con la expresión de los días hasta cuando aquel niño queda pagado y vestido; lo cual se ha de observar todas las veces que se despachen los niños con nuevas amas, y la primera cuenta con cada una se llevará a continuación de esta primera partida: observándose que siempre que las amas de afuera vengan a cobrar, traigan o los mismos niños o certificación de sus curas, que diga el estado que el niño tuviere y si está bien cuidado: a esta amas, cuando se las entreguen los niños, se dará una cédula que contenga el nombre del niño, y el folio a donde estuviere escrito en el libro grande: la cual cédula ha de traer siempre que vengan a cobrar. 


\section{Constitución XVII.}

De las amas que vinieren a dejar los niños.

En viniendo alguna ama a dejar el niño, que tenga en su poder, ha de reconocer la ama mayor si el niño trae algún mal contagioso, como sarampión, viruelas, sarna u otro mal semejante, que haya contraído en poder de aquella ama: y si así sucediere no se ha de consentir que le deje hasta que esté bien curado; pero si el niño no tuviere mal alguno de éstos, se la admitirá la dejación sin resistencia alguna, y el administrador la ajustará la cuenta, pagándola lo que se la debe y anotándolo al final de la partida, con la expresión de haber dejado el niño: si la ama, por haber poco tiempo que llevó el niño, debiere al Hospital algo de lo que se la adelantó, lo pagará; y si no lo pagase, se la detendrá por el ama mayor las envolturas o alguna otra prenda, hasta que pague, anotándolo a la margen de la cuenta y el niño se detendrá en el. Hospital, hasta que haya otra ama con quien despacharle.

\section{Constitución XVIII.}

De los muchachos y muchachas que no tienen paga.

Mientras que los muchachos hijos de este Hospital, no pudieren por si ganar la vida, y hasta tanto que las muchachas tomen estado, han de estar bajo el amparo del Hospital y dirección del administrador, de modo que siempre que se desacomoden de las casas en que se les tuviere puestos, y siempre que quedasen desamparados, 0 por muerte de los padres que los crien o porque los padres vengan a tal pobreza que no puedan mantener, o cuando entendiere el administrador que en las casas en que los crian los enseñan malas costumbres, se han de recoger y mantener dentro del hospital en sus respectivas habitaciones, dándoles la misma ración que está señalada a los del número: y ha de providenciar el administrador, que lo más presto que se pueda, se acomoden en otras buenas casas: las muchachas por medio de la ama mayor y los muchachos por medio del capellán, que habite en la casa de los muchachos, o por medio del visitador. Y porque la principal atención en cuanto a los muchachos la ha de poner el administrador en que aprendan oficio decente, con que puedan ganar de comer: si para esto fuere necesario dar alguna ayuda a costa al maestro, que los haya de enseñar, o vestir al muchacho a la entrada en casa del maestro, o por algún tiempo, asi se ha de hacer, concertándolo el administrador en lo menos que pueda, y obligándose el maestro por escritura a darle enseñado dentro de cierto tiempo, según se practique con los aprendices de aquel oficio. Si algún muchacho o muchacha se huyere de la casa en que se le tenga puesto, luego que lo sepa el administrador, dará orden al visitador para que a toda diligencia se le busque y se le traiga al hospital, a donde se le corregirá a discreción del administrador: y lo que costaren las diligencias para buscarle, se pagará del cau- 
dal del hospital, a cuya costa se ha de hacer siempre todo lo posible para que ningún muchacho ni muchacha se pierda. Con las personas que tuvieren en sus casas muchachos y muchachas que ni tienen paga, ni valen para ganar por sí la comida, ha de proceder el administrador con discreta moderación, de suerte que ni conceda todo lo que le pidan ni lo niegue todo; sino que vaya sobrellevando, dando de cuando en cuando algún vestido, camisa o calzado, lo que más necesitare el muchacho o muchacha, para que con este menos gasto se evite el mayor, que tendrá que mantenerle en el hospital: este gobierno se ha de llevar cuando los muchachos y muchachas, que no tengan paga, estén en casas que los crien bien: porque cuando no, aunque las personas que los tengan, no los quieran dejar, se les han de quitar y disponer de ellos, como va dicho de los que se desacomoden.

Constitución XIX.

De los niños que sus padres quieran sacar del hospital.

Si por el padre o madre de algún niño se le quisiere sacar del Hospital (o sea pidiéndole el padre o madre inmediatamente por si, o sea pondiéndole por medio de tercera persona) antes de todo, por parte de quien le pida, se ha de dar razón del tiempo en que el niño se echó al hospital, y de las señas que traía cuando lo echaron; y si cotejadas las señas que se dieren, con las que se hallaren escritas en la partida de su recepción, se hiciere juicio prudente de ser aquel mismo niño el que se pide, pagándosele al hospital todos los gastos que se hubieren hecho con aquel niño, se entregará a la persona que le pida, si fuere persona conocida, o la abonase sujeto que lo sea; en caso de que le conste al administrador que el padre o madre que quieren llevarse al niño, no tiene medios para pagar todos los gastos, se le entregará pagando lo que pudieren: y para lo que restare les prevendrá, que quedan con obligación de restituirlo al hospital, luego que puedan.

Constitución $X X$

De las prohijaciones.

Las personas que hubieren de prohijar niños o niñas de este Hospital, han de ser de buena opinión, han de tener algunas conveniencias y no han de ejercer los oficios más bajos: han de hacer escritura de prohijación en la forma acostumbrada ante el escribano del Hospital, y han de pagar el coste de la escritura, si no es que el administrador juzgare conveniente que le pague el Hospital; pues en tal caso, así el coste de la escritura como el vestir a la criatura, y aun dar alguna ayuda de costa de corta entidad al prohijante, lo ha de concertar el ad- 
ministrador de aquel modo que tenga más conveniencia al Hospital y redunde en beneficio de la criatura: hecho el concierto y traída razón del escribano de estar otorgada la escritura, se anotará la prohijación en el margen de la partida de recepción de la criatura prohijada, y en el libro grande al folio de su última cuenta: lo cual ejecutado, entregará al administrador la escritura al prohijante, advirtiéndole la obligación de justicia que ha contraído de alimentar y educar aquella criatura por todos los dias de su vida, como si fuese su hijo legítimo: quedando del cargo del administrador procurar que a la criatura prohijada se le guarden sus derechos: y porque estas prohijaciones nunca han der ser en perjuicio de las criaturas, se observará que si por muerte del prohijante, o porque se reduzca a tal pobreza que no pueda mantener a la criatura prohijada, o por otro motivo, viniese la prohijación a ser en daño de la criatura, se la restituirá al Hospital, y se la cuidará como a las demás que no están prohijadas.

Constitución XXI.

De los enfermos.

Luego que enferme algún muchacho o muchacha de los que vivieren dentro de este Hospital, se ha de hacer pronta diligencia para que le lleven a curar al hospital de la Misericordia o al hospital de San Juan Bautista (que llaman de afuera) y si no le recibieren en estos hospitales, o porque tuviere enfermedad de las que no admiten, o porque no hubiere cama desocupada, se enviará al hospital del Refugio: porque mientras que en este Hospital no se ponga enfermeria, no se ha de consentir en él curación de muchachos enfermos, que se pueden curar en otros hospitales: pero el administrador ha de tener cuidado de que los muchachos o muchachas que se lleven a curar a otros hospitales, en estando buenos vuelvan a éste: y si desde el hospital del Refugio los pasaren a Madrid para la curación del hospital General, alli se ha de prevenir persona segura, que esté a la vista del muchacho o muchacha, para que en mejorando, de modo que se pueda poner en camino, se avíe con persona de satisfacción para este hospital, de cuyo caudal se pagará el coste que hubiere de traerle. Si enfermare algún niño de pecho de los que están en la sala, se llamará médico o cirujano, según fuere el mal, y se hará cuanto convenga a la salud: en enfermando cualquiera de los niños, que estén con amas de fuera, ya sea de pecho ya sea de destete (que por pequeños no reciban en los hospitales) si fuere de los que se críen dentro de Toledo, ha de proveer el administador, que con cédula suya los asista médico o cirujano, el que conviniere: previniendo a uno y a otro que en las recetas de la botica, que juzgaren precisas, pongan el nombre y apellido del niño o niña para quien fuere: y las recetas no se han de despachar en la botica sin que también vayan firmadas del administador o de otra persona de su satisfacción, de que ha de estar instruido el boticario: previniéndole que no se le pagará receta que no estuviere firmada del administador o de la persona que señalare. $\mathrm{Si}$ el niño que enfermare fuere de los que se crían en los lugares, le ha de asistir 
el médico o cirujano del lugar a donde estuviere, sin que por ello lleve interés alguno: pues asi está mandado con pena de excomunión mayor "latae sententiae" por el edicto que el Consejo de la Gobernación expidió a favor de los niños hijos de este Hospital, en nueve de mayo del año pasado de mil setecientos cuarenta: y las recetas de la botica, que se ofreciere, las ha de firmar el cura del lugar, previniéndoselo así a los curas de los lugares el visitador del Hospital, cuando fuere a los lugares a visitar a los niños: si las amas, que criaren estos niños que enfermen, estuvieren notablemente necesitadas, y esto le constare al administador (por informe del médico o cirujano, para los que estén dentro de Toledo; y de los curas para los que estén en los lugares) se les dará una corta ayuda de costa, a discreción del administrador, para que mejor puedan alimentar a los niños mientras esién enfermos: cautelando el administrador, del modo posible, que estas ayudas de costa se conviertan en bien de los niños enfermos. Si enfermaren la ama mayor, la maestra de las niñas, el maestro de los muchachos, o las dos mujeres que cuiden de ellos, se podrán curar dentro del Hospital en sus respectivas habitaciones, acudiéndolos el Hospital con médico, cirujano y botica. Las dos amas de pecho, que estén en la sala, sólo se han de curar en ella de males ligeros, que no pasen de dos o tres días de cama, en los cuales se las asistirá como a la ama mayor; pero si contrajesen enfermedad, que necesite para su curación más tiempo que los dos o tres dias, se las ha de despedir, y se han de traer otras. Si a los que estén enfermos dentro del Hospital se hubieren de administrar los sacramentos, se acudirá para ellos a la parroquia de San Nicolás.

Constitución XXII.

De los impedidos $y$ achacosos.

A cualquier muchacho o muchacha de los hijos de este hospital que tuviere algún defecto grave corporal, o achaque habitual incurable, que le imposibilitare ganar la comida, aun después de cumplidos los siete años se le ha de continuar la paga, mayor o menor según fuere la edad y el mal que padeciere: de manera que a unos se les dará paga de destete regular, a otros de destete doble y a otros de pecho: lo que gobernará el administador a su discreción observando que a ninguno de los impedidos o achacosos se le dé paga mayor de la que fuere menester para ponerlos en poder de personas caritativas, que los tengan en sus casas y los cuiden bien. En caso de que ni la paga de pecho fuere bastante para encontrar personas de satisfacción, que se encargue, de mantenerlos, hará el administador que se dé memorial al cabildo, con relación a la edad y males que padezca el expósito para que el cabildo determine la paga que se le haya de dar: porque el administador por sí, no ha de poder señalar mayor paga que la de pecho. 
Constitución XXIII.

De los que tomaren estado.

Cuando alguna muchacha, hija de este Hospital, tratare de casarse, si pidiere parecer al admínistador, la aconsejará lo que la convenga: y llevándose adelante el matrimonio, se le darán por el administador las certificaciones necesarias, pero dinero ni ropa alguna de cuenta del Hospital no la dará sin decreto del cabildo: y porque estas criaturas regularmente no tienen quien miren por ellas, ni bienes algunos, el visitador, con acuerdo del administrador, dirigirá a la muchacha que trate de casarse en las diligencias que por parte de ella se hubieren de hacer; y si la muchacha estuviere tan pobre que no tenga para una cama, dispondrá el visitador que en nombre de la muchacha se dé memorial al cabildo, pidiendo el socorro que se suele dar en semejantes casos, y lo que el cabildo la mandare dar, se lo entregará el administador después que esté casada, tomando recibo del marido y anotándolo en el libro grande al folio correspondiente. Si acaeciere que alguna muchacha, o por haber contraído esponsales o por otra razón, tuviere derecho a que se case con ella alguno que se niegue a cumplir con su obligación, el administador (informándose bien del caso y hallando que la muchacha tiene justicia) dará orden al visitador para que se siga la causa ante el juez competente, sin que se omita diligencia que pueda conducir: y aunque al procurador notorio, y demás ministros, que intervengan en estas causas, no les ha de pagar derechos algunos, por ser práctica inconcusa que a las muchachas hijas de este Hospital se las defienda por pobres, no obstante, si para alguna diligencia extrajudicial, que al administador parezca conveniente, se necesitare gastar algún dinero, se pagará del caudal del Hospital. Si a alguna muchacha la llamare Dios para el estado de religiosa (como ha sucedido con diferentes) y reconociere el administador que podrá lograr su santo deseo, socorriéndola el Hospital con alguna limosna, ordenará que se dé memorial al cabildo, y la cantidad que se le mandare dar, se entregará después que la muchacha haya profesado y tomado recibo de la prelada. A los varones hijos de este Hospital, que se quieren casar, sólo les dará el administador las certificaciones convenientes: pero si alguno quisiere ser religioso, y no tuviere para los gastos de la entrada, dispondrá el administador que presente memorial al cabildo.

\section{Constitución XXIV.}

De los que murieren.

Los hijos de este Hospital que murieren dentro de él, luego que mueran se amortajaran con algún lienzo de poco provecho, y se llevarán a la capilla del Pradillo: si no pasaren de siete años, desde la misma capilla, a hora competente, se les sacará para sepultura, rezando el oficio el capellán semanero con el sacristán: si hubiere cumplido los siete años, desde la capilla del Pradillo se les 
llevará a la iglesia, y se les cantará vigilia y misa: después se les llevará a enterrar al Pradillo, cantando el oficio de entierro los dos capellanes con el sacristán: las sepulturas se han de abrir por el portero y, a falta suya, el mozo que asistiere en la casa de los muchachos, dando ocho maravedis por abrir cada sepultura. Los que murieren fuera del Hospital, si se criaren dentro de Toledo y no pasaren de dos años, se podrán traer a enterrar al Pradillo: y si se trajeren, se enterrarán como va dicho de los que mueren dentro del Hospital: los que pasaren de dos años, se han de enterrar por los curas de las parroquias a donde se criaren, dándoles sepultura dentro de las iglesias, y sentando partida en el libro de entierros, sin llevar por el rompimiento ni por el entierro derechos algunos: y esto mismo han de hacer los curas de los lugares con cualquier hijo de este Hospital que muera en sus feligresias, porque así está mandado en el edicto del Consejo de la Gobernación que se menciona en la Constitución XXI. A la ama del niño, que muere, si tuviere paga, se le ajustará la cuenta y se hará como se previene en la Constitución XVIII. En sabiendo el administrador que ha muerto algún niño, notará con esta señal la margen de la partida de su recepción, $y$ todas las partes adonde estuviere escrito en el libro grande. A los expósitos que mueren sin testar, y no tuvieren hijos, ni estuvieren prohijados, hereda el Hospital: y asi, en caso de que dejen algunos bienes, cuidará el administrador de que se vendan, y del dinero, que de ellos se sacare, se pagará el entierro, se dirán algunas misas por el difunto, y lo que pareciere al administrador se aplicará en beneficio del Hospital. Si muriere el administrador, o alguno de los ministros que viven dentro del Hospital, se ha de enterrar como parroquianos de San Nicolás.

Constitución $X X V$.

De la sala de las niñas de la labor.

El número de niñas que de pie fijo se han de mantener en la sala de la labor, le ha de señalar el cabildo en consideración de la renta corriente del Hospital: y el administrador ha de tener el cargo de escogerias entre las que fueren hijas de este Hospital, atendiendo a que sean de las que estuvieren en las peores casas, que tengan la edad de seis a ocho años, poco más o menos, y que no tengan defecto grave corporal ni achaque habitual: estas niñas, que compongan el número señalado por el cabildo (que al presente es de doce), se han de mantener dentro del Hospital y en la sala destinada para ellas, hasta la edad de doce años a lo menos, y de catorce a lo más: de manera, que en cumpliendo los catorce años, indispensablemente se las ha de sacar del número, aunque no estén bien impuestas en las labores, y se han de poner otras en su lugar; y si habiendo cumplido los doce años supieren ya bastante labor y estuvieren en poder de servir, se hará la diligencia de acomodarlas en casa competente: pero si no se las hallase conveniencia, no porque sepan bien las labores, se las ha de sacar del número hasta que cumplan catorce años. Si alguna persona de 
modo y conveniencias pidiere alguna de las niñas del número, antes que cumpla los doce años, o para prohijarla o para tenerla en su casa, juzgándolo conveniente el administrador, la dará, entrando siempre otra en lugar de la que saliere. En acomodar a estas niñas conforme vayan cumpliendo los catorce años y en cumpliendo los doce, si estuvieren diestras en las labores, ha de entender la ama mayor con noticia y aprobación del administrador, quien ha de anotar en el margen de la última partida, a donde la niña estuviere escrita en el libro de despensa menor, $y$ el libro grande en su último folio la persona con quien se pusiere a servir, y el salario en que se concertare. Las niñas, que fueren del número han de tener su dormitorio junto al de la maestra y separado del dormitorio de las muchachas grandes que vayan y vengan: de manera que cuando la maestra y las niñas del número tuvieren su dormitorio en el cuarto bajo y al contrario: evitando en todo lo posible el trato de las muchachas grandes con las niñas del número. Los recados que las niñas y las muchachas necesitaren para sus labores, se han de comprar a costa del Hospital, y la maestra, que se ha de entregar de ellos, dará cuenta al administrador de cómo se han gastado. Toda la labor que la maestra, las niñas del número, y las muchachas grandes hicieren, ha de ser cosa que pueda servir al Hospital, y solo cuando no tengan que hacer para el Hospital, podrán trabajar labores para afuera: y de lo que ganare por esto cada una, se ha de entregar, la ama mayor, y se lo ha de emplear, como se previene en la Constitución VII. La ración de cada una de estas niñas ha de ser medio pan y cinco cuartos por día, repartiéndoselo la ama mayor, como se previene en la Constitución VII. Sus vestidos se han de componer de guardapiés interior de cordellate amarillo, guardapiés exterior de guerguilla azul, y jubón de lo mismo, dos almillas de lienzo para el verano, dos pañuelos de bocadillo, una mantilla de bayeta blanca ordinaria, y tres camisas de Bierzo, con su señal para cada una, con más los zapatos que necesitaren. Han de dormir dos en una cama, que ha de ser de tablas, y ha de constar de jergón, dos sábanas de lienzo ordinario, una almohada larga de lo mismo, y en lugar de colcha, una cubierta de sayal o cordellate: al pie de cada cama ha de haber un serillo de estera, y han de ser proveídas de los vasos que fueren menester para la limpieza. En las ventanas de los cuartos, en que habiten las niñas del número, se han de poner encerados y cortinas a costa del Hospital; y el cuarto en que hagan labor, se ha de esterar el invierno. Cada una de las niñas y muchachas han de tener su rosario, y le han de traer al cuello.

\section{Constitución $X X V I$.}

De la maestra de las niñas y sus obligaciones.

La maestra de las niñas (que nombrará el administrador por el tiempo de su voluntad) ha de ser mujer provecta, diestra en todo género de labores, y que sepa leer, no ha de ser casada, ni ha de tener en su compañia hijo alguno varón: ha de habitar en la sala de la labor, y ha de tener su dormitorio inmediato a las 
niñas de número. Su obligación ha de ser enseñar a las niñas del número, y las demás muchachas que hubiere en la sala, las labores que más convenga a sus edades y habilidad: esmerándose mucho en instruirlas de modo que cuando lleguen a los catorce años, sepan con perfección aquellas labores que más las puedan aprovechar, como son coser todo género de ropa blanca, cortarla, hilarla, coser medias y calcetas, tejer listones, hacer cordones y botones, con los demás que convenga saber a una mujer: aplicando especialmente a cada una a la labor para que descubriere más ingenio: asi ha de ser obligación de la maestra enseñar a leer a todas las niñas del número, y educarlas en las buenas costumbres, teniendo de ellas todo aquel cuidado que debe tener una madre de sus hijos, excepto en lo tocante a comida y vestido, pues de esto ha de cuidar el ama mayor, a quien la maestra ha de avisar siempre que las niñas del número necesiten alguna cosa de vestir o calzar. También ha de ser obligación de la maestra ocupar en algunas labores a las muchachas grandes, que vinieren al hospital, porque se desacomoden: observando con estas muchachas no consentirlas que se junten con las niñas del número, sino es para hacer labor: la cual acabada, las mandará volver a su cuarto. Estas muchachas grandes, entretanto que se acomoden, han de estar sujetas a la maestra, de la misma manera que a la ama mayor; y así la maestra las ha de mandar, reprender, y castigar cuando pareciese, sin que se lo pueda estorbar la ama mayor: quien también las ha de mandar y castigar cuando lo juzgue conveniente: y sólo ha de estar la diferencia en que lo que las manda la ama mayor lo han de hacer primero, que lo que les mande la maestra: la labor que hiciere la maestra, como la que hicieren las niñas y las muchachas, ha de ser cosa que pueda servir al hospital, como se previene en la Constitución XXV. Los vestidos, camisas, medias, sábanas, colchones y cualquier otra ropa, que fuere menester, así para las niñas de número y muchachas grandes, como para los muchachos de la escuela, se han de hacer en la sala de la labor por la dirección de la maestra, a quien la ama mayor ha de avisar de todo lo que se haya de coser en la sala de la labor, entregándola los recados necesarios, quedando del cuidado de la maestra hacer que se cosan, y en estando cosidos volverlos a la ama mayor. La ropa blanca, y de vestir para los muchachos y muchachas la ha de cortar la maestra; y si algo no supiere cortar, hará la ama mayor que la demandadera lo lleve a algún sastre, y cortado lo dará a la maestra para que se cosa: asi mismo ha de cuidar la maestra de que estén hechos con prevención algunos pares de medias de lana, que puedan servir a los muchachos y muchachas; y todos los recados, que fueran menester para cualquier labor que han de hacer las niñas y muchachas, asi para enseñarse como para cosa que haya de servir en el hospital, los ha de pedir la maestra al administrador, o por sí misma o por medio del ama mayor: a la maestra se le ha de entregar por tercios o por meses el aceite señalado en el libro de despensa mayor para las luces de la sala de la labor, y para alhucema se la dará la mitad que a la ama mayor. También ha de cuidar la maestra de que esté alzada, y guardada en las arcas que ha de haber en la sala de labor, la ropa blanca y la de vestir que sirva a las niñas del número: su ración ha ser un pan, una libra de carne, y diez maravedis cada día, y el salario veinte reales al mes, pagados por tercios, médico, cirujano, botica, casa y agua. 
Constitución XXVII.

Del modo con que las niñas de la labor han de tener repartido el tiempo en los dias de trabajo.

Uno de los principales cuidados de la maestra ha de ser que las niñas del número tengan bien repartido el tiempo: para lo cual se ha de observar que desde el primer día de abril hasta el último de septiembre, se levanten de cinco a seis de la mañana; y desde el último de septiembre hasta el primero de abril, de seis a siete: luego que se levanten, hará la maestra que se hinquen de rodillas delante de la imagen de Nuestra Señora que está en el dormitorio; y que asi arrodilladas, se persignen, digan el acto de contricción, y recen el credo, la salve y el alabado, diciendo primero la maestra y repitiendo las niñas: después las hará que levanten sus camas, limpien el cuarto, se laven y se peinen: en tocando a misa en la iglesia del Hospital, irán todos los días a oírla, así las niñas del número como las demás muchachas que hubiere en la sala, y detras de todas, así a la misa como al rosario, ha de ir la maestra siempre que pueda: cuando no pudiere, lo avisará al ama mayor para que vaya con ellas o envíe a alguna de las amas de pecho, que no hiciere falta: al ir a la iglesia y al volver a la sala, guardarán toda compostura y silencio: dentro de la iglesia para oir misa y para rezar el rosario, se pondrán niñas y muchachas en el escalón de arriba de la capilla mayor a la mano derecha, y la maestra, o la ama, que vaya en su lugar, se han de poner detrás de todas, procurando que estén con mucha devoción, sin hablar unas con otras; y a la que en esto faltare, se la castigará rigurosamente: en viniendo de misa, tomarán el desayuno que las diere el ama mayor, y en dando las ocho en verano y las nueve en invierno, se pondrán a hacer labor, asi las niñas del número como las muchachas grandes que estuvieren desocupadas, las niñas a un lado, las muchachas grandes a otro, y la maestra en medio: antes de empezar la labor, se hincarán todas de rodillas, se persignarán y rezarán el Padrenuestro y el Ave Maria con el Gloria Patri, etc., diciendo primero la maestra y repitiendo las niñas: hecha esta breve oración, se aplicará cada una a su labor, guardando toda quietud y silencio, y la maestra hará su oficio, teniendo en la mano una caña y unas correas para castigar a la que se descompusiere, según lo merezca. En dando las once pondrán las niñas del número sus labores en cobro, y tomará cada una su cartilla o su libro y estudiarán las lecciones: en pasando un breve rato empezará la maestra a tomarlas la lección, y conforme la vayan dando se volverán a sus puestos, a pasar la lección que la maestra las hubiere echado para la tarde: ínterin que las niñas del número estén dando la lección, las muchachas grandes se mantendrán quietas en sus puestos, haciendo sus labores: en dando las doce se hincarán todas de rodillas, y rezarán la oración del Alabado, diciendo primero la maestra y repitiendo las niñas: luego con silencio y compostura pondrán las muchachas grandes sus labores en cobro, y las niñas sus cartillas o libros en la alacena, retirándose la muchachas grandes a su cuarto, se quedarán las niñas en la sala con la maestra, hasta que la ama mayor las llame a comer: en comiendo se volverán las niñas a su sala y las muchachas grandes a su cuarto, se quedarán las niñas en la sala con la maestra, hasta que 
la ama mayor las llame a comer; en comiendo se volverán las niñas a su sala y las muchachas grandes a su cuarto, a donde se divertirán unas con otras con honestidad y sin ruido hasta la una y media en invierno y hasta las dos y media en verano; pasado este tiempo de sosiego, tomarán las niñas del número sus cartillas o catones, repasarán sus lecciones, y en breve rato empezará la maestra a tomarlas la lección y las echará la que hayan de dar a la mañana siguiente: en este ejercicio de leer ha de gastar la maestra como una hora; en acabando las lecciones, hará llamar a las muchachas grandes y tomarán sus labores, haciendo para empezar la misma oración que por la mañana; a las cuatro de la tarde en invierno y a las cinco en verano, enviará la maestra a la mayorcita de las niñas del número a que la ama mayor la dé el pan para la merienda; y traído, le repartirá la maestra por su mano. En poniéndose el sol en invierno y entre las seis y la siete en verano, dejarán la labor y, para acabarla, harán lo mismo por la mañana. En el tiempo que hubiese desde que dejen la labor hasta que toquen al rosario, harán lo mismo que por la mañana. En el tiempo que hubiese desde que dejen la labor hasta que toquen al rosario, harán sus camas; y las de las niñas, que ellas no pueden hacer, las harán las muchachas grandes que señalare la maestra: y lo mismo se ha de guardar para cualquier hacienda que se ofrezca en la sala de la labor y las niñas del número no lo puedan hacer. Si quedare algún tiempo, y le hiciere bueno, consentirá la maestra que salgan al pradillo hasta que toquen al rosario: en tocando, irá cada una por su mantilla y con ella puesta esperarán hasta que la maestra las mande caminar a la iglesia: lo cual han de hacer, como queda dicho del tiempo de ir a misa. El dia que hubiere doctrina después del rosario, acabado que sea, se pondrán todas con buen orden al lado derecho del capellán, y se mantendrán de rodillas todo el tiempo que dure la doctrina; la cual acabada, y dando lugar a que primero se retiren las muchachas, se volverán ellas a su sala. Desde el último día de octubre hasta el primero de abril, en el tiempo que hubiere desde que se acabe el rosario y doctrina, hasta las ocho, las ocupará la maestra en las labores que juzgare más propias para aquella hora; en dando las ocho alzarán la labor; a esta hora en invierno, y en viniendo del rosario en verano, irán a cenar: en cenando, si hiciere tiempo frio, se retirarán a sus dormitorios; y si hiciere buen tiempo, se saldrán al Pradillo, divirtiéndose sín alboroto y con honestidad, hasta que la maestra las mande acostar: que nunca ha de pasar de las diez en verano ni de las nueve en invierno; antes de empezarse a desnudar hará la maestra que se hinquen todas de rodillas, que se persignen, y recen un Padrenuestro y un Ave María con su Gloria Patri al Angel de la Guarda, y otro al santo de su nombre: concluida esta oración, tomarán todas agua bendita y se acostarán todas, recorrerá la maestra las camas, y las acomodará la ropa; lo cual hecho se retirará la maestra a su dormitorio, llevándose la luz o apagándola. 
Constitución XXVIII.

Del modo con que las niñas del número han de tener repartido el tiempo en los días de fiesta.

En los días de fiesta se han de levantar a la misma hora que en los días de trabajo: y han de hacer lo mismo que queda prevenido en la Constitución antecedente, hasta venir de misa y desayunarse: depués se ocuparán a discreción de la maestra en lo que conviniere para la limpieza de la sala, y de las mismas niñas, o en prevenir lo que fuere necesario para las labores del dia siguiente; $y$ en el tiempo que quedare hasta las diez, se entretendrán en recreos honestos; en dando las diez, tomará cada una su cartilla o libro y repasarán sus lecciones: en breve rato las tomará la maestra la lección, y las echará la que hayan de dar la mañana siguiente; en acabando de dar las lecciones, se llamará a las muchachas grandes y la maestra o alguna de las niñas, que sepa leer bien, leerá la vida de algún santo o en otro buen libro estando todas muy atentas a lo que se leyere, hasta que den las doce: después irán a comer y harán como queda dicho en los dias de trabajo: pasado el tiempo de la siesta, juntará la maestra las niñas del número y las muchachas grandes, y como una hora las ejercitará preguntándolas oraciones de la doctrina cristiana: para este ejercicio hará la maestra que las niñas del número, que sepan leer, lleven aprendido un capitulo de la explicación de la doctrina, como está en el catecismo, y que le digan entre dos, las que la maestra alli señalare, diciendo una de las preguntas, y otra las respuestas; y si la pareciere a la maestra, podrá hacer que vuelvan a repetir el capítulo otras dos, como lo hicieron las primeras: lo que quedare de tiempo hasta cumplir la hora, le gastará en hacer preguntas de la doctrina cristiana ya a una muchacha ya a otra, y en enseñar las oraciones a las que no supieren: el ejercicio del capítulo sólo se ha de tener en los domingos, señalando de un domingo para otro el capitulo de doctrina que hayan de llevar: en los demás dias de fiesta, gastará la maestra toda la hora en enseñar oraciones y hacer preguntas de las que trae el catecismo: cumplida la hora de doctrina, si fuere tiempo de verano, se leerá un rato, o por la maestra o por alguna de las niñas, prosiguiendo la lección de por la mañana; y cuando a la maestra le pareciere, hará que se deje: acabada la lección en verano, y la doctrina en invierno, harán sus camas y después se entretendrán en recreos honestos en el Pradillo, si hiciere buen tiempo o en sus habitaciones, si le hiciere malo: siempre apartadas las muchachas grandes de las niñas del número: en tocando al rosario, harán como queda dicho en los días de trabajo: en el invierno, el tiempo que hubiere desde que vengan del rosario hasta las ocho, le emplearán en repasar sus lecciones, o en lo que a la maestra le parezca más conveniente: en dando las ocho en invierno, y en viniendo del rosario en verano, harán hasta acostarse como queda prevenido en la Constitución de los días de trabajo. 
Constitución $X X I X$.

Del recogimiento que se ha de guardar asi en la sala de los niños de pecho como en la de las niñas de la labor.

Ningún hombre de cualquier estado o calidad que sea, ha de entrar en la sala de niños ni en la de las niñas, ni en la cerca llamada el Pradillo, sin licencia expresa del administrador, quien ha de cuidar mucho de que ni sus criados entren sino es a cosa muy precisa. Las puertas grandes del Pradillo han de estar continuamente cerradas, y las llaves han de estar en poder de la ama mayor, quien no las ha de entregar sino es a persona que viva en el Hospital, y para diligencia que no se pueda excusar: la ama mayor día ninguno, ni la maestra en los dias de trabajo, han de poder salir del hospital sin licencia del administrador: en los días de fiesta podrá la maestra salir a lo que se ofrezca, sin pedir licencia; pero siempre que salga ha de llevar en su compañia a lo menos una niña de las del número, y podrá llevar dos o más si la pareciere: observando que una vez lleve a una y otra a otras: los días de fiesta por la tarde, si hiciere buen tiempo, podrá la maestra llevar a pasear al campo a las niñas del número, a todas o algunas, como mejor le pareciere: la ama mayor y la maestra no han de poder salir a un mismo tiempo del hospital; y siempre que salga una lo ha de avisar a la otra, para que cuide de las dos salas, hasta que venga la que saliere. Las amas de pecho no han de salir del Hospital, ni aun de la sala de los niños, sin licencia de la ama mayor, quien no las ha de consentir que salgan del Hospital sino es con motivo que importe: y cuando salieren, han de llevar en su compañia alguna muchacha, o niña del número, la que señalare la ama mayor. Las niñas del número, ni las muchachas supernumerarias, por ningún caso han de salir del Hospital sino es en compañía del ama mayor, maestra, amas de pecho o de la demandadera: ni tampoco han de salir de su sala a la de los niños, sino es que se lo mande la ama mayor o la maestra; y acabado de hacer lo que se las mande, se han de volver a su sala: cuando salieren del Hospital la ama mayor, maestra o alguna de las amas de pecho, con la circunstancias que van expresadas, si fuere por la mañana, han de volver al Hospital antes de las once; y si fuere por la tarde, han de volver antes del anochecer. Mientras la misa y mientras el rosario (cuando se rece en la iglesia) ha de cuidar el ama mayor que queden siempre en la sala de los niños dos mujeres, por lo menos, de guarda; las cuales, si en el Hospital no hubiere más que una misa antes, o después de ella, irán a oírla al Carmen.

Constitución $X X X$.

De la demandadera y barrendera.

Para traer de afuera del Hospital todos los recados, que sean menester en la sala de los niños y en la de las niñas, nombrará el administrador una deman- 
dadera que no ha de ser casada ni ha de tener en su compañia muchacho alguno: ha de vivir en el cuarto que está al pie de la escalera del segundo patio, y ha de ser su obligación hacer todo lo que la manden la ama mayor y la maestra: asi mismo ha de ser su cargo barrer los tránsitos, escaleras, corredores y segundo partio del Hospital con más el ámbito de la iglesia fuera de la capilla mayor: en tal conformidad que de quince en quince dias, por lo menos, ha de dar una vuelta general de escoba a todos los sitios expresados, excepto el ámbito de la iglesia, que ese le ha de barrer de ocho en ocho dias: si en el intermedio hubiere algún sitio notablemente sucio, le ha de barrer luego, no siendo como recado para la sala de los niños o de las niñas, no ha de poder salir del Hospital sin licencia de la ama mayor: su ración ha de ser una real y un pan para cada día, y su salario doce ducados, pagados por tercios: con más de cuatro pares de zapatos y dos mantellinas cada un año, y para escobas se le ha de dar lo que está señalado en el libro de despensa mayor.

Constitución $X X X I$.

De la casa de los muchachos.

En la nueva casa, que se ha hecho al lado izquierdo de la iglesia del Hospital, ha de haber continuamente el número de muchachos que el cabildo señalare: los que el administrador ha de elegir de los hijos de este Hospital, que no sean notablemente defectuosos ni tengan enfermedad habitual, prefiriendo a los que estuvieren en peores casas: su edad para entrar en el número ha de ser de seis a ocho años. Estos muchachos, que compongan el número señalado por el cabildo (que al presente es de veinticuatro) se han de mantener en el Hospital hasta tanto que sepan leer, escribir y contar con perfección: en sabiéndolo, luego se procurará acomodarles en casas de oficiales de buenos oficios para que se los enseñen: observando lo que se previene en la Constitución XVIII. Si algún muchacho saliere rudo, de manera que a los dos años de estar en el número no supiere leer, sin esperar a más se le hará diligencia de ponerle en alguna casa decente en que pueda aprender a ganar la vida, entrando otro en su lugar. Los que aprendieren competentemente, se han de mantener en el número hasta la edad de trece años, si antes no se perfeccionaren en el escribir y contar; pero en cumpliendo los trece años, indipensablemente se les ha de sacar del número y se han de entrar otros: a los que salieren del número, ínterin que se les halle conveniencia, se les mantendrá en supernumerarios, asistiéndolos y educándolos como a los del número, pero sin echarlos semana de oficio: y de supernumerarios el tiempo que más han de poder estar, ha de ser un año: porque mientras que en este Hospital no se enseñe a los muchachos otra cosa que leer, escribir y contar, ningún muchacho ha de haber en él que pase de catorce años: y asi, al que los llegue a cumplir, en el mejor modo que se pueda, se le ha de sacar del Hospital. Si por persona de modo y conveniencias se quisiere sacar alguno de los muchachos del número, o para prohijarle o para tenerle en su casa, conven- 
drá el administrador, si lo juzgare conveniente, y pondrá otro muchacho en el lugar del que saliere. También se han de recoger en esta casa de muchachos hijos de este Hospital que no teniendo catorce años se desacomodaren de las casas en que se les tenga puestos, según se previene en la Constitución XVIII, y a los muchachos que, por cualquiera de las causas que en la citada Constitución se expresan, se recogieren en esta casa, ínterin que se acomoden, se les ha de tratar como a supernumerarios. Los vestidos de todos estos muchachos han de ser de cordellate pardo, gorra de lo mismo, zapatos de los más ordinarios y camisa de Bierzo, teniendo siempre hechas y señaladas tres camisas para cada muchacho. La ración de cada uno ha de ser cinco cuartos por día, los que la ama, que los cuidare, les ha de repartir en almuerzo de algún poco de fruta o queso, comida y cena caliente, como se practica con las niñas del número; y por la tarde se les dará para merendar un poco de pan sólo: en cuanto a pan se observará que, para almorzar y merendar, se reparta un pan de dos libras entre ocho muchachos y para comer y cenar un pan entre seis: han de comer y cenar juntos en el refectorio, sentándose por el orden con que hayan entrado en el número, y a cada uno se ha de poner su ración de pan y vianda aparte. Su dormitorio le han de tener en el cuarto, que se le ha hecho en la nueva casa para este fin y han de dormir dos en cada cama: sus camas han de ser como las de las niñas del número, y se han de acostar y levantar todos a la misma hora. En las ventanas del refectorio, dormitorio y escuela ha de haber encerados de lienzo en invierno, y una estera al pie de cada cama. Para el cuidado y enseñanza de estos muchachos, han de vivir dentro de la nueva casa, en las habitaciones separadas (que se han hecho con ese destino), uno de los capellanes del hospital, un maestro de niños, dos mujeres de gobierno y un mozo para los recados.

\section{Constitución XXXII.}

Del maestro de niños $y$ sus obligaciones.

El maestro, que para enseñanza de los muchachos del número ha de nombrar el administrador, ha de ser el que se hallare más a propósito para el ministerio, no sólo diestro en escribir y contar, sino de las más sanas costumbres, y señalada prudencia: ha de tener su habitación en la casa de los muchachos, en la vivienda que se le tiene destinada, y podrá ser casado. Su obligación ha de ser enseñar a leer, escribir y contar a todos los muchachos hijos de este Hospital que hubiere en la casa y a los que se criaren dentro de Toledo y vinieren a la escuela; pero no ha de poder enseñar a muchacho alguno que no sea hijo de este Hospital: asimismo ha de ser de su obligación instruir a los muchachos del número y supernumerarios en la doctrina cristiana, y educarlos en todas las buenas costumbres: ha de asistir todos los dias en el refectorio mientras los muchachos coman y cenen y ha de estar a su vista cuando se acuesten: se ha de entregar y responder de las mesas, bancos y demás trastos que sirvan en la 
Escuela, cuya llave ha de tener, cuidando de que no esté abierta, sino en las horas precisas: también ha de estar en su poder la llave de la puerta que sale al corral y jardín, que llaman del sacristán, y sólo ha de consentir que se abra esta puerta cuando los muchachos salgan a esparcirse por aquel paraje, haciendo que, cuando vuelvan, cierren la puerta y le traigan la llave: ha de tener escuela todos los dias que no fueran fiestas de precepto, a excepción del jueves y viernes santos, de los días del triunfo y exaltación de la Santa Cruz y de las tardes de víspera de comunión: ha de ofrecer a los muchachos el rosario en el sitio de la casa que fuere más a propósito, en el tiempo de invierno, en que el capellán semanero vaya a ofrecerle a la sala de los niños: ha de acompañar a los muchachos, siempre que vayan juntos a la iglesia, y cuando salieren del Hospital: no ha de salir de la casa de los muchachos no siendo con ellos, sin dar cuenta al capellán que alli viviere: ni ha de poder hacer viaje fuera de la ciudad sin licencia del administrador: ha de proveer a su costa a los muchachos de escribir, de la tinta que necesitaren, y se ha de quedar con los pliegos que escribieren. La comida se la han de guisar en la cocina de su vivienda, si no es que no tuviere mujer alguna en su habitación, que en tal caso le podrán guisar en la cocina de los muchachos pagando el guiso. Su salario ha de ser de dos mil doscientos reales de vellón, pagados por meses, médico, cirujano, casa y agua del aljibe.

\section{Constitución XXXIII.}

Del capellán que viviere en la casa de los muchachos.

Para el mejor gobierno de la casa de los muchachos, ha de habitar en ella continuamente uno de de los dos capellanes del Hospital, el que señalare el administrador: este capellán, además de las obligaciones comunes a los dos capellanes, que se expresan en la Constitución $X X X X$, ha de tener también la de atender a que los muchachos, asi del número como supernumerarios, que hubiere en la casa, se eduquen bien: que el maestro cumpla exactamente con su ministerio; que la ama de los muchachos, y su compañera, cuiden con todo esmero de la comida, ropa y limpieza de los muchachos: y que el mozo haga con puntualidad y fidelidad cuanto se le mande conveniente al servicio de la casa; y de cualquier defecto grave que notare en el debido orden y gobierno de la casa, ha de dar cuenta al administrador para que ponga el remedio. Ha de corregir y reprender a los muchachos, siempre que lo juzgare oportuno; y cuando supiere de algún muchacho que ha cometido delito que merezca castigo se lo ha de avisar al maestro para que le castigue como mereciere. Ha de multar al mozo de la casa en la ración o en el salario, cuando faltare en algo al cumplimiento de su obligación, pero sin que la multa pueda exceder de cuatro reales, porque siendo falta que merezca más castigo, to ha de avisar al administrador. Ha de tener continuamente en su poder la llave de la puerta de la casa, que sale a la portería del Hospital, y no ha de consentir que se abra esta puerta sino para 
diligencia extraordinaria conducente al servicio de la casa: porque para todo lo ordinario se ha de mandar por la puerta principal, que sale al corredor del patio grande: así mismo se ha de tener la llave de la leñera, que está junto al calentador de los muchachos, y la del mismo calentador: y ha de cuidar de que en el tiempo de mucho frío, un rato después de comer y otro rato después de cenar, se les encienda a los muchachos un poco de lumbre: para lo cual ha de disponer que se compre con tiempo la leña, que fuere a propósito, procurando que no se gaste de la precisa, y el dinero que costare la leña, con sola su declaración, se lo dará al administrador, y lo cargará al Hospital en gasto extraordinario: en habiendo estado los muchachos a la lumbre como una hora, ha de hacer que se cierre la leñera y el calentador, y ha de recoger las llaves. En un libro, como el de despensa mayor que le ha de dar el Hospital (cuyo título ha de ser "Memorial de los muchachos del número") ha de tener por asiento todos los muchachos que fueren del número, expresando en las partidas los nombres y los apellidos de los muchachos, la edad que tuvieren (que ésta se la notificará al administrador) y el día que entraren en el número: por el cual libro se gobernará para saber cuándo cumplen los trece años: y dos meses antes que los haya de cumplir cualquiera de los muchachos del número, lo ha de avisar al administrador para que provea de otro que entre en lugar del que cumpliere. Así mismo ha de ser obligación de este capellán diligenciar con dirección del administrador que se acomoden los muchachos del número luego que cumplan los trece años, o antes si se hubieren perfeccionado en escribir y contar: y siempre que se acomode alguno, ha de anotar al margen de la partida de su asiento el nombre del amo con quien se acomodare y el oficio a que se le pusiere. En la misma conformidad ha de intervenir a la orden del administrador, en que se comode con la brevedad posible cualquier muchacho hijo de este Hospital que se desacomodare de la casa en que se le tuviere puesto; y para el acomodo de estos muchachos ha de tener presente lo prevenido en la Constitución XVIII. También ha de ser de su obligación, luego que enferme cualquiera de los muchachos, providenciar que cuanto antes se pueda, se lleve a curar a alguno de los hospitales de enfermos, observando para esto lo ordenado en la Constitución XXI. Este capellán ha de tener en su poder, recibiéndolo del administrador, cuanto los muchachos necesitaren para su escuela, como es cartilla, catones, libros de espejo, belarminos, catecismos, papel, plumas y tinteros: lo que irá dando a los muchachos según lo que fueren necesitando; y así mismo los ha de proveer de rosarios, cuidando de que cada uno tenga el suyo y le traiga al cuello: al maestro le ha de dar el papel que necesitare para muestras, parces, nombramientos de oficios y tablas, que sirvan para la enseñanza de los muchachos. Cuando el maestro le dé cuenta de que tiene que salir de casa, convendrá en ello, pudiéndose él estar en casa hasta que venga el maestro: porque (si no es con grave urgencia) no han de faltar de casa los dos a un tiempo; y cuando sucediere, el último que salga lo ha de avisar a la ama para que esté a la vista de los muchachos entre tanto que venga alguno de los dos. En ausencias y enfermedades del maestro, ha de asistir a los muchachos en todos los ministerios del maestro; a este capellán le han de guisar la comida en la cocina de su habitación; y no ha de tener más renta que el otro capellán, porque con la mejor habitación se le compensa el trabajo mayor. $\mathrm{Si}$ 
quiere que le guisen la comida en la cocina de los muchachos, ha de pagar el guiso.

Constitución XXXIV.

De las dos mujeres que han de cuidar de los muchachos.

Han de vivir continuamente en la casa de los muchachos, en los cuartos que se han hecho con este destino, dos mujeres, de las cuales la una, que ha de tener el nombre y oficio de ama, ha de ser de señalado modo y gobierno: no ha de estar casada, y la ha de nombrar el administrador por tiempo de su voluntad: la otra, que se ha de llamar ayudanta, la ha de elegir el ama con aprobación del administrador, y entre las dos han de cuidar de la comida, ropa y limpieza de los muchachos. La ama se ha de entregar por inventario de mano del administrador, o de persona de su satisfacción, de toda la ropa, espetera, ollas, calderos, vidriado, vasijas de barro y demás trastos que sirvan en el refectorio, dormitorio, cocina, despensa y otras oficinas de la casa, y ha de responder de ello. Lo que fuere vidriado, y vasijas de barro convenientes al servicio y limpieza de los muchachos, se le ha de dar por primera vez de cuenta del Hospital: mas el reponer lo que se quiebre, ha de ser de cuenta de la ama; como también ha de ser de su cuenta reponer las sogas que se gastaren en los pozos, dar todas las escobas que se necesitaren para barrer, y el espliego que fuere necesario para sahumar: para lo cual se la han de dar cuarenta y cinco reales al año, pagados por tercios: por lo respectivo a ropa, espetera, y demás trastos de que se entregare a la ama que no sean de barro, siempre que algo se quebrare o se consumiere, ha de dar cuenta al administrador para que se reponga o se la baje del inventario; asi mismo se ha de entregar al ama del pan para los muchachos, y de los cinco cuartos de su ración (del pan diariamente, y de la ración por semanas, una anticipada) y se to ha repartir en un almuerzo, comida, merienda y cena según queda prevenido en la Constitución XXXI. El almuerzo se le ha de dar todos los días en viniendo de misa, la comida luego que den las doce, la merienda a las cuatro en el invierno y a las cinco en verano, y la cena en saliendo del rosario; el almuerzo y la merienda se lo repartirá la ama desde su habitación; mas para comer y cenar, media hora antes entrará la ama en el refectorio y pondrá las mesas con manteles (que ha de tener guardados) pondrá para cada muchacho su ración de pan separada, y hecho esto, se retirará a la cocina: desde allí por la ventana, que sale al refectorio, les enviará la vianda a cada uno en su platillo vidriado de los más ordinarios. La ama y su ayudanta han de lavar en las pilas de la casa toda la ropa blanca, que sirva a los muchachos, y la han de echar lejia; para lo cual, y para lavar su ropa, se le ha de dar una cuartilla de jabón cada mes. Así la ropa blanca, como los vestidos y medias de los muchachos, lo han de remendar siempre que convenga; y los recados, que se necesiten para remendar, los ha de pedir la ama al administrador; cuando fuere preciso hacer alguna ropa de nuevo, que haya de servir a los muchachos, o para sus camas 
- para sus vestidos, la ama ha de avisar al administrador para que la mande dar los recados necesarios; y entregándose de ellos, los llevará a la ama mayor para que los haga coser en la sala de labor; y en estando cosidos, la maestra los volverá a la ama mayor y ésta los enviará con la demandadera a la ama de los muchachos: quien también ha de cuidar de que en tiempo oportuno se les remienden los zapatos y el coste que tuviere le pedirá al administrador. Cuando los muchachos necesitasen zapatos nuevos, lo avisará al administrador para que los mande hacer. Asi mismo ha de tener esta ama de su obligación proveer a los muchachos de camisa limpia y medias todos los sábados por la tarde, poniéndoles en las camas a cada uno su camisa y su par de medias bajo de la almohada, al lado que se acostare. La ropa blanca de las camas se le ha de poner limpia de mes a mes: y este día, y los sábados han de hacer todas las camas de los muchachos entre la ama y su compañera: los demás días se han de hacer las camas los mismos muchachos. Ha de correr de cuenta de ésta mantener la lumbre que fuere menester en la cocina de los muchachos para guisarles la comida y la cena; y desde mediados de noviembre hasta mediados de febrero, ha de dar para la escuela, los días que la hubiere, un brasero por la mañana y otro por la tarde: para lo cual, y para las lejias, se le han de dar por ef Hospital doscientas y sesenta arrobas de carbón al año; y así mismo ha de correr de su cuenta y cuidado encender el farol de la escalera principal de la casa todas las noches, luego que toquen las oraciones, previniéndole de aceite de modo que arda hasta las once de la noche; y al punto que toquen al rosario ha de poner luz en un farol, que alumbre al maestro y a los muchachos para ir al rosario: ha de mantener también dos velones encendidos que alumbren a los muchachos en los sitios que hubieren de estar, desde que vengan del rosario hasta que se acuesten; para estas luces, y una que alumbre al ama y a su ayudanta, se la han de dar cinco arrobas de aceite cada un año, con mas los faroles y velones que se necesiten; han de estar en poder de esta ama las llaves de todas las oficinas de la casa excepto las que haya de tener el capellán y maestro como se previene en las Constituciones. Todos los días por la mañana ha de dar una vuelta al dormitorio de los muchachos, le ha de sahumar bien con espliego y romero, y ha de aliñar lo que estuviere sucio o mal puesto. Si algún muchacho enfermare (en el interim que se lleve a curar a alguno a los hospitales de enfermos) le ha de cuidar con mucha caridad, poniéndole puchero aparte y asistiéndole con cuanto fuere menester, y el dinero, que para esto fuese necesario, le pedirá al administrador, dándole después puntual cuenta de lo que haya gastado con el enfermo. A esta ama, para ella y su ayudanta, se le ha de dar de ración libra y media de carne, tres libras de pan y veinte maravedis cada día; de salario treinta y tres reales cada mes, pagados por tercios. 
Constitución XXXV.

Del modo con que los muchachos han de tener repartido el tiempo los dias de trabajo.

La principal atención del maestro se ha de ordenar a que los muchachos aprovechen el tiempo, teniéndole bien repartido; para lo cual observará que desde primero de abril hasta primero de octubre se levanten de cinco a seis de la mañana, y desde primero de octubre hasta primero de abril de seis a siete, despertándolos el mozo de la casa. Luego que se levanten, hará que se hinquen de rodillas delante de la santa cruz, que estará en su dormitorio, y que canten a media voz introducción a la doctrina cristiana que empieza: Todo fiel cristiano, hasta acabarse de persignar; después al mismo tono dirán el Padrenuestro, y el Ave María, el Credo y la oración del alabado, diciendo primero el maestro, o el muchacho que tuviere el oficio de lector, y repitiendo los demas; acabada la oración, en el tiempo que hubiere hasta que toquen a misa, han de doblar la ropa de sus camas y levantar el colchón, cada dos muchachos la cama en que durmieren; y las camas de los que por muy chicos no to pueden hacer, las levantarán los que tuvieren el oficio de roperos; éstos, y los que tuvieren el oficio de barrenderos, luego que hayan levantado las camas, sacarán los vasos de limpieza y los enjuagarán con agua que allí estaba prevenida, dejándolos en aquel sitio hasta la noche; después los barrenderos barrerán todos los dias el dormitorio y el cuarto donde estuvieren entre dia; conforme se vaya desocupando, irán todos a lavarse la cara y las manos en la pila, a donde el mayor de los roperos ha de tener prevenidas dos toallas de lienzo recio, en que todos se limpien; después se peinarán con peines, de que ha de cuidar el mismo que cuida las toallas; y a los chicos, que no sepan peinar, los peinarán entre los dos roperos. En habiéndose todos lavado y peinado, se volverán al dormitorio si hiciere frío; y si no, se mantendrán en el corredor o en el patio hasta que toquen a misa, diciendo todos en voz alta, a misa, a misa, irán a la puerta de la iglesia, y allí de la parte de adentro esperarán hasta que vaya el maestro. Cuando durmieren en el cuarto de verano, han de salir a oír misa a la iglesia; y cuando duerman en el cuarto de invierno, han de ir a oírla a la tribuna que está en la capilla mayor: en llegando el maestro, entrarán en la iglesia con mucha compostura y silencio, de dos en dos, llevando los brazos cruzados: y siempre que salgan a la iglesia, se hincarán de rodillas en filas de seis, del escalón abajo de la capilla mayor al lado izquierdo, inmediato al escalón y a la tarima del altar del Santo Cristo de la Justicia, y el maestro se pondrá siempre en la tarima de dicho altar: de forma que a todos los muchachos los tenga cerca y a la vista: en llegando a aquel sitio los dos que tuvieren el oficio de monaguillos, se encaminarán con toda modestia a la sacristía (cuando salieren a oir misa por la tribuna, en llegando el maestro a la puerta, le harán los dos monaguillos la venia, y marcharán por la puerta de abajo a la sacristía) a donde entrarán, y luego que vean al sacerdote, le harán un profundo acatamiento, doblando la cabeza y el cuerpo sin hablar palabra: asistirán al sacerdote mientras se revista, y saldrán delante de él muy compuestos y apareados a ayudarle a misa; la cual acabada, volverán de- 
lante del sacerdote a la sacristía, parándose en la puerta uno a un lado y otro a otro, dando lugar a que entre primero el sacerdote, y al entrar le harán la dicha reverencia debida; después entrarán ellos, y asistirán al sacerdote mientras se desnuda; en acabándose de desnudar, se hincarán de rodillas delante del sacerdote y le besarán la mano; en besándosela, se levantarán y le harán otro profundo acatamiento y se volverán como vinieron al sitio donde estén los compañeros, los cuales se han de mantener de rodillas hasta que vuelvan los monaguillos; en llegando, se levantarán todos, y con el mismo orden y compostura, que salieron para la iglesia, se volverán a casa; luego irán al ama a que les dé el desayuno; en tomando el desayuno, marcharán los dos barrenderos al cuarto del maestro y le pedirán la llave de la escuela, irán a ella y la barrerán, limpiarán los bancos con una rodilla, que han de tener prevenida, y lo pondrán todo como debe estar; en dando las ocho en tiempo de verano (esto es cuando duerman en el dormitorio bajo) y las nueve en tiempo de invierno (esto es cuando duerman en el dormitorio alto) irán todos a la escuela, a donde el maestro les hará guardar toda quietud y compostura, y los ejercitará con buen orden a cada uno en lo que anduviere, hasta las once y media: a esta hora hará el maestro señal para que se hinquen de rodillas $y$, así puestos, cantarán las oraciones que pareciere al maestro, terminando siempre con la oración del alabado: después pondrá cada uno su cuartilla, o libro en cobro, y se irán al dormitorio o al patio, según fuere el tiempo; cerrando el maestro la escuela y llevándose la llave; en dando las doce irán a comer, y antes de sentarse, conforme vayan entrando en el refectorio, se irán poniendo delante de las mesas en pie con el mismo orden que se hayan de sentar; así puestos, y con los brazos cruzados, se mantendrán hasta que venga el maestro; en viniendo, se pondrá en el sitio que haga cabecera, inclinándole los muchachos la cabeza al tiempo que pase, y en llegando a su sitio rezarán el credo, diciendo primero el maestro y repitiendo los muchachos: acabado el credo, echará el maestro la bendición, y después se sentará cada muchacho en su lugar, guardando toda compostura y silencio mientras estén comiendo; los dos muchachos que tuvieren el oficio de refitoleros, han de servir la comida a los otros, uno por cada lado; y el que tuviere el oficio de lector, ha de estar leyendo la vida de algún santo o en otro buen libro, hasta tanto los otros coman; en acabando de comer, hará el maestro señal dando una palmada sobre la mesa, y cesando de leer el lector, se mantendrá en pie en su sitio, los demás dejarán sus puestos y se pondrán delante de sus mesas, como estuvieron antes de sentarse; los dos refitoleros se pondrán también en fila, ocupando el primer lugar cada uno en su lado, y en esta forma rezarán el Padrenuestro, el Ave María, el Gloria Patri, etc., y la oración del alabado: después, quedándose en el refectorio los dos refitoleros y el lector, se pondrán a comer, y los servirán la comida los dos barrenderos: en acabando de comer éstos, el lector y los refitoleros se irán con los otros, y los barrenderos volverán a la cocina el vidriado por la ventana del refectorio, levantarán los manteles, los doblarán, poniéndolos en el sitio que deban estar y barrerán el refectorio: lo cual hecho, el más antiguo de los barrenderos cerrará el refectorio, y llevará la llave a la ama: en el tiempo que hubiere desde que acaben de comer, hasta las dos en invierno y las tres en verano, se entretendrán en recreos honestos, sin meter mucho ruido, en el sitio que el maes- 
tro los ordenare; en dando las dos en invierno y las tres en verano, irán a la escuela, y harán como por la mañana, excepto que a las cuatro en invierno y a las cinco en verano, se levantará el más antiguo de los refitoleros y pidiendo licencia al maestro, irá a la ama a que le dé el pan de la merienda, traerá en una cesta tantos pedazos de pan como muchachos hubiere, y el maestro se los repartirá, haciendo volver al ama la cesta: poco antes de ponerse el sol, hará el maestro señal para que se hinquen de rodillas, y cantarán las mismas oraciones que por la mañana: excepto los sábados que han de cantar la salve y la letanía de Nuestra Señora, diciendo primero el maestro o el lector, y repitiendo los demás: acabadas las oraciones los soltará, e inmediatamente irán a hacer las camas, cada dos la suya; y las de aquellos, que por muy chicos o por otra causa no las puedan hacer, las harán los roperos: en habiendo hecho las camas, irán los roperos y los barrenderos al lugar común, traerán los vasos de la limpieza y los pondrán debajo de las camas; después se entretendrán honestamente en el sitio que el maestro le ordenare, hasta que toquen al rosario: en tocando, el lector irá a por el farol, que la ama ha de tener prevenido y tomándole se encaminará al cuarto del maestro para alumbrarle cuando baje, y los demás acudirán prontamente a la puerta de la iglesia y allí, de la parte de adentro de la casa, esperarán hasta que baje el maestro: en bajando, pondrá el farol en la poyata, que estará a la entrada de la iglesia, y dejándole allí encendido hasta la vuelta, se incorporará con los otros: que para entrar al rosario, harán como va dicho del modo de entrar en misa: acabado el rosario los dias que hubiere doctrina, subirán el escalón arriba de la capilla mayor, y en filas de a seis se pondrán de rodillas delante del capellán a su lado derecho, dando lugar a que con toda separación puedan estar las muchachas al lado izquierdo: así de rodillas se mantendrán todo el tiempo que dure la doctrina, respondiendo a lo que el capellán preguntare, y el maestro en sitio que lo pueda oír, estará en pie o sentado: en acabándose la doctrina, y cuando no la hubiere el rosario, se volverán a la casa con el mismo orden y compostura que entraron en la iglesia (cuando el capellán rezare el rosario en la sala de las niñas, a la misma hora le han de rezar ellos en su casa con el maestro, asistiendo primero a la salve los días que la hubiere): en volviendo del rosario, tomará el lector el farol, y caminando delante de todos irán a cenar: en llegando a la puerta del refectorio, volverá el lector el farol al ama y entrarán todos a cenar, observando lo mismo que para comer: excepto el leer en el libro y barrer el refectorio, pues esto sólo se ha de hacer el mismo día. En cenando se irán a entretener al patio en verano y a su cuarto o al calentador en invierno, hasta que el maestro los manda acostar, que nunca ha de pasar de las diez en verano ni de las ocho en invierno: todos se han de ir a acostar a un tiempo: y en estando juntos, antes de empezarse a desnudar, se pondrán de rodillas delante de la santa cruz, y diciendo primero el maestro, o el lector, y ripitiendo los demás, rezarán un Padrenuestro y un Ave María con su Gloria Patri al Ángel de la Guarda, otro al santo de su nombre y otro al santo de aquel dia. Terminando con la oración del alabado: hecha esta oración, tomarán todos agua bendita, santiguándose con ella, la echarán sobre sus camas y se acostarán rezando el credo y la salve mientras se desnuden; manteniéndose, entre tanto, a 
su vista el maestro, quien habiéndose acostado todos, recorrerá las camas, y se retirará a su dormitorio, llevándose la luz o apagándola.

Constitución $X X X V I$.

Del modo con que los muchachos han de tener repartido el tiempo en los dias de fiesta.

En las fiestas de precepto se levantarán a la misma hora que en los dias de trabajo, y harán lo mismo hasta venir de misa, y desayunarse: luego irán de dos en dos al cuarto del ama; y si fuere domingo, llevará cada uno la camisa y medias que se haya quitado y lo entregará al ama: hasta que salgan los dos que entren primero no han de entrar otros, y así sucesivamente irán entrando de dos en dos por sus antigüedades, diciendo: Alabado sea el santísimo Sacramento al tiempo de entrar, y esperando los otros de la parte de afuera de la puerta: la ama conforme fueren entrando (después de recibir la camisa y las medias el dia que lo lleven) los peinará y recoserá; reprendiendo al que fuere desaliñado; a los que necesiten de que se les saquen las liendres, y a todos los que tuvieren mucho que recoser, los mandará que vuelvan a otra hora en que pueda estar más desocupada, porque en esta hora no ha de hacer con ellos más que peinarlos lo más preciso: conforme vayan saliendo del cuarto de la ama, los que supieren leer se irán por los sitios comunes de la casa a estudiar de memoria el capítulo de la doctrina cristiana que el maestro les hubiere señalado; y los que no supieren leer, se aplicarán a aprender las oraciones de la doctrina, que debieren llevar estudiadas, ayudados de los que las sepan, a quienes el maestro 10 encargare: en dando las diez irán a la escuela y allí los ejercitará el maestro de la doctrina cristiana una hora por lo menos: este ejercicio de doctrina se ha de tener todos los días de fiesta, que vinieren solos: cuando vengan dos dias de fiesta juntos, en el segundo; y si vinieren más de dos, en el primero y en el último: el ejercicio ha de empezar diciendo el capítulo entre los dos, los que alli nombrare el maestro, uno las preguntas y otro las respuestas; en acabándole de decir los dos primeros, se retirarán a sus puestos, y nombrará el maestro otros dos que salgan a decirle en la misma forma, de suerte que el capítulo se diga por cuatro a lo menos: al que diga el capítulo sin errar (sea preguntando o sea respondiendo) le dará el maestro dos parces; al que yerre sólo dos puntos, le dará un parce y errar siete puntos será siempre delito de azotes, que no se redimirán sino con dos parces: acabado el capítulo, irá diciendo cada uno la oración, que el maestro le hubiere mandado aprender y el tiempo que quedare hasta cumplir la hora, la gastará el maestro en hacer preguntas sueltas de la doctrina cristiana, ya a uno ya a otro, poniendo especial cuidado en enseñar por sí oraciones principales a los pequeños y a los rudos; por fin del ejercicio señalará el maestro el capitulo y oraciones que hayan de aprender para la doctrina siguiente: en habiendo muchachos, que hayan dado todo el catecismo de memoria, el primer domingo de cada mes, a la misma hora que en los otros dias 
de fiesta, se ha de tener ejercicio general de doctrina cristiana en esta forma: un muchacho de los que mejor sepan la doctrina (que el maestro nombrará de un mes para otro) se pondrá en asiento algo elevado, al otro extremo de la escuela frente al maestro, al cual cada uno de los otros muchachos, levantándose por su orden, le hará una pregunta de doctrina a su elección; y si respondiere a todas las preguntas sin errar siete puntos, se le dará el víctor; si los errase, se le dará cola, uno y otro que pareciese al maestro; y a los demás muchachos, que hicieren mejores preguntas, les dará parce. Acabado el ejercicio de doctrina, en el tiempo que tuviere hasta las doce, se entretendrán en recreos honestos: en dando las doce irán a comer y harán lo mismo que queda dicho en los dias de trabajo, hasta las tres en verano y las dos en invierno: a estas horas en los domingos, que saliere el rosario de San Pedro Mártir por las calles, los llevará el maestro al rosario, haciendo que vayan con buen orden y mucha compostura, llevando el lector delante una cruz grande, en la forma que la usa el Hospital, y presidiéndolos el maestro: irán cantando las oraciones de la doctrina cristiana hasta la iglesia de adonde saliere el rosario; y acabado, se volverán al hospital en la misma forma: en los días de fiesta, que no hubiere rosario, pasado que sea tiempo de sosiego, se repartirán por los sitios comunes de la casa a estudiar el capitulo y las oraciones, en lo que emplearán hasta las cinco en verano y hasta las cuatro en invierno; en volviendo del rosario, los domingos que le hubiere, y en los dias de fiesta, que no le haya, en pasando las horas de estudio les dará la ama la merienda: en merendando irán a hacer sus camas, y hasta que no toquen al rosario se entretendrán honestamente en el sitio que el maestro les ordenare: en tocando el rosario irán a él, y hasta acostarse harán como en los dias de trabajo: en las tarde de fiesta, que hiciere buen tiempo, y no saliere el rosario de San Pedro Mártir, a la hora que pareciere al maestro (y después que hayan hecho sus camas) podrán salir juntos al campo por parajes apartados del paseo común, para que con más libertad puedan hacer ejercicio y entretenerse, acompañándolos siempre el maestro o alguno de los capellanes, quien ha de proporcionar el paseo de modo que al toque de oraciones estén de vuelta en casa.

Constitución XXXVII.

De los oficios que los muchachos del número han de servir por semanas.

Entre los muchachos del número de más edad, ha de repartir el maestro los oficios de comunidad, que los muchachos han de servir por sí, en la conformidad siguiente: para ayudar a misa, hacer lo que se ofrezca concerniente al culto divino, y proveer de agua bendita las pilillas de la casa, se han de nombrar dos, que se han de llamar monaguillos: para leer en el refectorio, rezar el primero con los otros en la ausencia del maestro, y traer y llevar las luces a donde convenga, se ha de nombrar uno que se ha de llamar lector: para servir la comida y ministrar el agua, con lo demás que fuere necesario en el refectorio, se han de nom- 
brar dos, que se han de llamar refitoleros: para cuidar la ropa, y limpieza de todos en ausencia del ama, se han de nombrar dos, que se han de llamar roperos: para barrer los sitios, que habitaren los muchachos y sacar los vasos de la limpieza, se han de nombrar otros dos, que se han de llamar barrenderos: y para tener cuenta con lo que los otros hicieren, que no sea de hacer y avisarlo al maestro, se ha de nombrar uno que se ha de llamar celador: estos oficios los han de servir los muchachos que fueren del número por semanas, y el nombramiento lo ha de hacer el maestro, extendiéndolo en medio pliego de papel, sin expresar en él más que los nombres de los oficios, y los de los muchachos que los hayan de servir en esta forma:

\section{MONAGUILLOS}

N.

N.

\section{LECTOR}

N.

y así los demás: extendiendo de esta forma el nombramiento, lo ha de publicar el maestro todos los sábados por la tarde al acabar la escuela: y en habiéndose publicado, lo ha de fijar en la puerta de la escuela por la parte de afuera, en donde se mantendrá toda la semana; los oficios han de correr de cargo de los nombrados, desde que el maestro los publique, y en un mismo oficio (excepto el de celador) no se ha de nombrar a un muchacho en una semana dos, o más oficios, cuyos servicios no sean incompatible; publicado el nombramiento, ha de instruir el maestro a cada uno de los nombrados en lo que le tocare por su oficio; $y$ al que incurriere en falta, según ella fuere, le ha de castigar el maestro. Si además de los cargos, que aquí van explicados para cada oficio, se ofreciere alguna otra diligencia dentro de la casa, que los muchachos puedan hacer, sin faltar a la escuela, el maestro en su discreción la agregará al oficio que le parezca. Cuando el maestro averiguare que el celador no le ha notificado algo malo, que haya visto en los otros, al celador y al delincuente los ha de dar igual castigo; también ha de ser obligación del celador suplir las faltas de los que no cumplieren con sus oficios, o por descuido o porque no puedan.

Constitución XXXVIII.

Del mozo de la casa de los muchachos y de sus obligaciones.

Para hacer lo que se ofreciere fuera de la casa y traer a ella los recados necesarios, ha de nombrar el administrador un mozo de buenas constumbres, que no sea casado, el cual ha de vivir dentro de la casa, en el cuarto que se ha hecho con este destino, y ha de tener la obligación de hacer todo lo que le manden el ama, el capellán y el maestro. Este mozo ha de despertar todos los 
días a los muchachos a la hora que se deban levantar, y para cuando se levantaren ha de tener prevenida de agua la pila en que se hayan de lavar, y la que estuviere en lugar común, para enjuagar los vasos de la limpieza. Ha de subir todos los días con el tiempo a la cocina de los muchachos el agua y el carbón que sea menester; y hecho esto, saldrá a los recados que se ofrezcan fuera de la casa, atendiendo primero a lo que le mande el ama: poco antes de comer y de cenar ha de llevar todos los dias al refectorio el agua del aljibe, que los muchachos necesitaren para beber; en los ratos que tuviere desocupados, ha de barrer todos los días los corredores en invierno, y el patio en verano, y de ocho en ocho días ha de barrer todos los sitios comunes de la casa. Si no fuere mandado del capellán, ama, o maestro, no ha de salir de casa sin licencia del capellán: a falta de portero ha de abrir en el Pradillo las sepulturas que se necesiten para enterrar, y las ha de volver a cubrir, dándole, en tal caso, los ocho maravedis que se habia de llevar el portero. Su ración ha de ser pan, media libra de carne, y diez maravedís cada día, y su salario veinte reales cada mes, pagados por tercios. Si quisiere se le guisará en la cocina de los muchachos, pero ha de pagar el guiso al ama.

Constitución $X X X \mid X$.

$\mathrm{Del}$ visitador de los niños y sus obligaciones.

Conforme la Constitución XXVI de las antiguas, ha de nombrar el administrador (para el tiempo de su voluntad) un visitador de los niños, que sea persona de toda confianza, sacerdote si se hallere a propósito; y en caso de que alguno de los capellanes del Hospital fuere sujeto, que lo pueda y sepa bien hacer, ha de ser preferido: este visitador ha de ser obligado a celar continuamente si las amas de pecho cuidan bien de los niños que tienen a su cargo, y si las que tienen niños de destete los crían y educan como es debido: también ha de inquirir de todos los muchachos y muchachas hijos de este Hospital que no tuvieren paga ni hubieren tomado estado, si es que están bien acomodados, y de los que hallare que no lo están, a la orden del administrador ha de diligenciar que se acomoden lo mejor que se pueda. Dentro de Toledo ha de visitar en sus casas todos los niños de pecho, y destete dos veces al año, y más las que el administrador le ordenare, informándose por la vecindad del trato que las amas dan a los niños. Ha de ser obligado a salir dos veces al año, en los tiempos que pareciere al administrador, por los lugares del contorno de Toledo a donde se crien niños de este Hospital, concertando el camino de manera que no rodee y llevando por memorial los niños que hubiere en cada lugar, los nombres de las amas que los criaren, las edades de los niños, y las señas más notables de cada uno, para que no le muestren unos niños por otros: en los lugares se ha de informar directamente por personas prudentes y timoratas de la calidades de las amas y de sus modos de cuidar los niños: visitándolos también en sus casas para que más bien se certifique de su estado y asistencia: si hallare que alguno de los 
niños ha muerto, cobrará de la ama la librea y el dinero que le hubiere sobrado, para lo cual ha de llevar el poder del administrador: quien también le ha de dar sus cartas generales para los curas y justicias de los lugares, pidiéndoles que por el servicio de Dios den al visitador todo favor y ayuda para hacer lo susodicho. Ha de encargar a los curas que si alguno de los niños de este hospital, de los que estuvieren en su feligresía, enfermaren, procuren que el médico o cirujano les asistan de balde, conforme a lo mandado por el edicto del Consejo de la gobernación, mencionado en la Constitución XXI, y que si para su curación fuere preciso algún medicamento de la botica, firmen las recetas. Ha de averiguar en cada lugar si se mantiene fijado en la sacristía el sobre dicho edicto del Consejo; y a donde no le hubiere, dejará un tanto autorizado al cura para que lo haga fijar: no ha de ir a lugar a donde no haya a lo menos tres niños de este Hospital: además de las dos visitas ordinarias cada año, ha de salir también a los lugares que siempre conviniere, para el bien de los niños a discreción del administrador. $Y$ de todo lo que hallare en las visitas, así dentro como fuera de Toledo, ha de dar puntual relación al administrador para que provea según cumpliere. $\mathrm{Ha}$ de hacer a la orden del administrador cualquier diligencia, que se ofreciere provechosa a los hijos de este Hospital, que no hubieren tomado estado. Su salario ha de ser mil y cien reales de vellón, pagados por tercios, y se le han de dar veinticuatro reales de vellón cada día de los que ocupare en la visita de los lugares.

\section{Constitución $X X X X$}

De los capellanes $y$ sus obligaciones.

Siempre ha de tener este Hospital dos capellanes, sacerdotes seculares amovibles "ad nutum" del administrador: y conforme a la Constitución IX de las antiguas, los sacerdotes que se recibieren por capellanes de este Hospital, han de estar expuestos de confesores, y no han de tener beneficio curado, ni simple servidor, ni servicio de beneficio alguno en las iglesias de la ciudad, para que no tengan otra ocupación que la del Hospital; sus obligaciones han de ser las siguientes: Bautizar en caso de necesidad, "sub conditione", todos los niños que echaren a este Hospital en lo prevenido en las Constituciones IV y V, y para lo segundo en lo ordenado en la Constitución XXIV decir la misa diaria en la fundación de la iglesia de este Hospital, a las siete de la mañana desde el primer día de abril hasta el último de septiembre: y a las ocho desde el primer día de octubre hasta el último de marzo, renovar el Santísimo Sacramento de la Eucaristía de quince en quince días, en el jueves: cantar Vísperas y Misa en las fiestas de la Santa Cruz y en las dotadas por el señor don Domingo de Mendieta: bendecir agua siempre que sea menester: deslavar los corporales y purificadores cuando el sacristán se lo avise: confesar y dar comunión a los muchachos y muchachas de este Hospital (que tuvieren edad para ello y licencia del párroco) los dias expresados en la tabla que está en la sacristía; confesar y dar comunión 
a las amas y ministros del Hospital siempre que quisieren: cantar la salve inmediatamente antes del rosario todos los dias de Cuaresma, todos los sábados del año y las visperas de las festividades de Nuestra Señora, que refiere la tabla, que está en la sacristía: advirtiendo que los sábados despues de la salve se ha de cantar un responso por el fundador: asistir todos los días (al toque de oraciones de la santa iglesia) al rosario y ofrecerle: observando que desde el primer día de Cuaresma hasta el último de noviembre, se ha de rezar el rosario en la iglesia del Hospital, delante del altar mayor; y desde el primer dia de diciembre hasta el martes de Carnestolendas en la sala de los niños, delante de la imagen de Nuestra Señora del Rosario, que alli está fijada: enseñar y explicar la doctrina cristiana a los muchachos y muchachas del Hospital, inmediatamente después del rosario, en el tiempo de Cuaresma los lunes, miércoles y domingos: y en los demás del año los jueves y domingos: ir en la procesión de los niños que va a la santa iglesia el día de la Natividad de Nuestra Señora y volver con ella hasta entrarla en la iglesia del Hospital: recibir con sobrepelliz y bonete en la puerta del Hospital la procesión de letanía, el día que el ilustrísimo cabildo baja con ella al Carmen, las funciones a que han de asistir ambos capellanes, son : visperas y misa en los dias de la Invención. Triunfo y Exaltación de la Santa Cruz; vísperas y misa en las fiestas dotadas por el señor don Domingo Mendieta que son: Navidad de Nuestro Señor Jesucrito, Asunción de Nuestra Señora, Santo Domingo y San Francisco; procesión de los niños a la santa iglesia; recibir la letanía, entierros de muchachos adultos y confesar los días de comunión. Las demás obligaciones arriba dichas las han de cumplir por semanas; y siempre que alguno no pueda hacer lo que sea de su obligación, ha de suplir por él el otro capellán o ha de buscar a su costa sacerdote de afuera que cumpla: si fuere para decir misa podrán valerse de religiosos; mas para las otras funciones ha de ser sacerdote secular. Cuando alguno de los capellanes faltare a lo que sea de su obligación, sin buscar sacerdote que supla por él, ha de perder la distribución que correspondiere al punto a que faltare, aplicándose la mitad de la distribución al Hospital, y dando la otra mitad al sacristán; si bien en lo que faltare alguno de los capellanes no hubiere distribución, el administrador a su discreción corregirá la falta. En ocurriendo fiesta, que tenga misa cantada, se ha de celebrar a la misma hora que se habia de decir la misa rezada de fundación; y ésta la dirá el capellán semanero en la semana siguiente; a las vísperas y misas cantadas en los entierros de los muchachos grandes y en las procesiones han de bajar sobrepelliz y bonete suyo. La renta de cada capellán ha de ser de cincuenta ducados al año, pagados por tercio, un pan cada día y agua del aljibe. Por las misas de fundación que cada capellán dijere, le ha de dar el receptor cuatro reales de limosna por cada misa: y por la asistencia a las fiestas de la santa cruz, a las dotadas por el señor don Domingo de Mendieta, a los entierros de muchachos grandes, y a la procesión de los niños, les dará el administrador el estipendio que consta en el libro de despensa mayor. 
Constitución $X X X X I$.

Del sacristán y de sus obligaciones.

El sacristán (que nombrará el administrador) ha de ser un mozo honrado, de buenas costumbres, que tenga buena voz y sepa canto llano: ha de vivir dentro del Hospital, en la habitación que le señalare el administrador: y ha de ser de su obligación cuidar de todos los ornamentos y alhajas, que sirven al culto divino, así en la iglesia como en la sacristia, entregándose de todo por el inventario que está en el libro de despensa mayor, de mano del administrador, en la vista de iglesia y sacristía, que deberá hacer dentro del primero mes de su administración, y ha de responder de ello en otra tal visita, que el administrador ha de hacer dos meses antes de cumplir su administración: ha de oficiar las visperas y misas cantadas en las tres fiestas de la santa cruz, y en las cuatro dotadas por el señor Mendieta, previniéndoles a los capellanes la víspera por la mañana; ha de cantar las salves y responsos de fundación, y los oficios que se ofrecieren por los adultos hijos de este Hospital, que murieron dentro de él; ha de asistir a todos los entierros de los hijos de este Hospital que se enterraren en el Pradillo, y luego que supiere haber muerto alguno, ha de avisar al capellán semanero para que señale la hora en que se haya de hacer el entierro; ha de ser muy puntual en prevenir el recado para la misa diaria de la fundación y para cualquier otra misa que se quiera decir en la iglesia del Hospital; a los sacerdotes que fueren a decir misa, los ha de tratar con todo respeto y agrado; a los dos capellanes del Hospital ha de ser muy obediente en lo respectivo a funciones de iglesia, $y$ al administrador ha de dar cuenta de cualquier falta que hubiere en lo tocante al culto divino y decencia de los ornamentos; en las misas rezadas que dijeren en la iglesia del Hospital, ha de ayudar con sobrepelliz, siempre que no hubiere persona decente que no ayude; y en habiendo renovación, aunque haya quien ayude, se ha de mantener toda la misa al lado del altar, ministrando a su tiempo la gradilla y lo demás que convenga; ha de asistir todos los dias al rosario y a la doctrina, cuando se tuvieren en la iglesia; y en entrando en ella el capellán semanero o para decir misa o para ofrecer el rosario, ha de tocar un rato la campanilla en la puerta del crucero de la iglesia, en la parte de afuera, de modo que se oiga en la sala de la labor y en la porteria; y lo mismo ha de hacer siempre que se diga misa en la iglesia del Hospital. En los dias señalados para que confiesen y comulguen los muchachos y muchachas del nümero, ha de prevenir las formas y lo demás que se necesite para las comuniones, a que ha de asistir indispensablemente; $y$ en estos día de comunión, luego que abra la sacristía, ha de abrir las rejas de la puerta principal de la iglesia y en el verano las puertas grandes del cancel, cuidando de cerrar una y otras como una hora después que se dé la comunión. El día antes de los días de comunión, ha de avisar a un confesor religioso para que venga la víspera, y el día de la comunión por la mañana a ayudar a los capellanes a confesar, $y$ al religioso se le ha de dar una limosna de cuatro reales, que pedirá al administrador; ha de esmerarse mucho en la curiosidad de los ornamentos y limpieza de los altares; y todos los sábados, y las vísperas de comunión ha de barrer la capilla mayor de la iglesia: ha de 
cuidar la lámpara que está delante del altar mayor, y de la que está delante del altar del Santo Cristo de la Justicia, previniendo una y otra de aceite de modo que ardan sin cesar de dia y de noche; ha de tener mucho cuidado con el jueves que tocare la renovación, previniendo lo necesario y advirtiéndoselo al capellán semanero, a quien también ha de avisar siempre que necesite bendecir agua, y cuando hubiere que deslavar corporales y purificadores; ha de ser de su cargo encomendar con tiempo el sermón de honras por el señor fundador, tomando la orden del administrador, y llevando al predicador el libro de la vida del señor fundador, que ha de recobrar lo más presto que pueda, volviéndole al cuarto del administrador, a quien ha de pedir el escudo que se acostumbra dar al predicador, y se le ha de entregar luego que predique; y asi mismo ha de pedir al administrador el estipendio que se acostumbra a dar al preste y diáconos, que celebren la misa de honras, y se le ha de repartir en la sacristía inmediatamente que se desnuden. Para la procesión de los niños ha de providenciar todo to necesario, avisando con tiempo a la parroquia y previniendo al tamborilero y a los que hayan de llevar el pendón del Hospital, la cruz y los ciriales; antes que salga la procesión ha de repartir las velas a las amas, a los capellanes del Hospital y a los clérigos que vinieren con la parroquia; ha de ordenar la procesión disponiendo que salga a tiempo, que llegue a la santa iglesia poco antes de acabar tercia; y en volviendo la procesión al Hospital, ha de ayudar a distribuir la propina a las amas. Ha de ser de su cargo traer a la orden del administrador la cera que se necesite para la procesión de los niños, aniversario del señor fundador, y gasto de entre año; como también de que se lleve a la santa iglesia la cera que se acostumbra para que arda en los sepulcros del eminentísimo señor fundador y del eminentísimo señor Portocarrero mientras las vísperas y misas de Todos los Santos, y vísperas y misas de las ánimas, llevando la razón el administrador de la cera que se gastare. Otrosi ha de ser de su obligación gobernar el reloj y darle cuerda a las horas convenientes: su renta ha de ser seiscientos y treinta reales, pagados por tercios, un pan cada día, casa y agua del aljibe. Para las dos lámparas, que han de correr de su cuidado, se le han de dar doce arrobas de aceite y media arroba para untar el reloj. Por los oficios cantados, entierros de muchachos adultos, asistencia a la procesión de los niños, para incienso el día del aniversario y para escobas, se le dará lo señalado en el libro de despensa mayor. Las seis arrobas de carbón, que se le daban antes para los braseros, que se ponían en las honras del señor fundador, por celebrarse en el rigor del invierno, se le han de dar ahora para que en los meses de diciembre y enero tenga un brasero en la sacristía al tiempo que se vaya a decir misa. La cera, que entre año se gastare en la iglesia, lo que costare lavar la ropa, componer los corporales, las hostias y tres maravedís para el vino de cada misa, se le ha de pagar del caudal del Hospital, llevándole al administrador al fin de cada mes, puntual cuenta de lo que en razón de ello se hubiere gastado, y de las misas que se hubieren dicho. Para recibir la letanía el día que el cabildo baja con ella al Carmen, ha de buscar un sacerdote que salga con la capa, un hombre que saque la cruz y dos muchachos, que lleven los ciriales, a quienes ha de dar el estipendio que se acostumbra, pidiéndole al administrador. 
Constitución XXXXII.

Del portero y sus obligaciones.

Para el oficio de portero ha de nombrar el administrador una persona de maduro juicio que sea caritativo y goce de buena salud; ha de habitar en el cuarto contiguo a la puerta principal del Hospital, y ha de ser su obligación recoger todos los niños que echaren al torno; y luego que los echen, llevarlos a que los vea el administrador, y desde allí pasarlos a la sala de los niños y entregárselos al ama mayor; si el administrador no estuviere en casa, o los niños se echaren a deshora, desde el torno los llevará derechamente a la ama mayor; al tiempo de tomar los niños del torno, ha de mirar con todo cuidado si con el niño se ha puesto algún papel u otra cosa que pueda servir de señal, y lo ha de entregar con el niño. Para que a cualquier hora de la noche que echaren los niños pueda al punto oírlo el portero, ha de haber siempre en su cuarto, de la parte de adentro, una campana pendiente de cuerda que salga fuera del Hospital y caiga donde está el torno, de forma que fácilmente se pueda tocar por los que vinieren a echar los niños. Ha de ser continuo cuidado del portero no consentir que en tocando a las oraciones haya gente alguna detenida en todo lo que coge la lonja del Hospital, para que no sirva de estorbo a los que vinieren a echar niños. Todas las noches ha de cerrar con llave las puertas principales del Hospital (en invierno a las diez y en verano a las once) y en todo tiempo las ha de abrir luego que amanezca: en tocando las oraciones ha de encender el farol que está en el patio de la sala de los niños y el que está en el atrio de la portería, previniéndoles de aceite, de modo que el primero arda toda la noche y el segundo hasta las diez en invierno y las once en verano. Otrosí ha de ser obligación del portero tocar un rato el esquilón que está fijado sobre la puerta del Hospital, con la cuerda que cae a la portería, al punto que el sacristán toque la campanilla a misa y al rosario. Su ración ha de ser un pan y una libra de carne cada día, y su salario veinticuatro ducados al año, pagados por tercios: con más doce arrobas de carbón y agua del aljibe; y para la luz de los faroles se ha de dar cinco arrobas de aceite por año. Mas se le han de dar veinticuatro reales, con la obligación de traer los ramos y hierbas odoriferas que fueren menester para enramar la lonja y echar en la iglesia el día de la letanía, en que el cabildo hace estación en la iglesia del Hospital.

Constitución XXXXIII.

Del mayordomo y sus obligaciones.

Por cuanto con las nuevas providencias que se han establecido en el gobierno de este Hospital, se han aumentado mucho los cargos del administrador, para que mejor pueda cumplir con ellos, relevándose de lo dispuesto por las Constituciones antiguas, en cuanto a la parte de escribir de su propia mano todas 
las partidas de los libros que sirven al gobierno de este Hospital, podrá nombrar de su cuenta y riesgo la persona que fuere más de su satisfacción con el nombre de mayordomo ( que viene expresado en los libros del hospital desde su fundación) el cual en lugar de las obligaciones, que se le prescriben en la Constitución $X$ de las antiguas, tendrá desde ahora en adelante la de ayudar al administrador en el asiento de los libros, en la paga de amas y ministros, en el recibo y gasto de los cordellates y lienzos, y en dar expediente a todo to que se ofreciere en el despacho que el administrador no pueda hacer por sí. Para su salario, en vez de los cinco mil maravedís que a este ministro se le daban antes, señaló el cabildo mil y cien reales de vellón en cada año.

Constitución $X X X X I V$.

Del receptor $y$ de sus obligaciones.

La persona que el cabildo nombrare para receptor de este Hospital ha de tomar las órdenes del cabildo en cuanto pertenezca al recobro de las rentas que estuvieren de su cargo, y al reparo de las casas que fueren del Hospital. Ha de aprontar al administrador en moneda de plata las cantidades de dinero que le pidiere para la manutención del Hospital, tomando recibo. Ha de proveer a la orden del administrador de los cordellates, guerguillas y lienzos ordinarios que fueren menester, surtiéndose de todo con prevención por los medios que tuviere menos costa, y tomando recibo del administrador, con expresión de las varas de ropa que le entregare. Ha de comprar con la conveniencia posible el carbón y el aceite que sea necesario para el gasto del Hospital, en las cantidades que constaren en el libro de despensa mayor $y$ ha de repartir a cada ministro lo que se le hubiere señalado. Ha de cobrar la refacción que toque al Hospital, procurando se dé toda la que corresponda. Ha de pagar por tercios a los capellanes del Hospital las misas de su fundación que certificaren haber dicho en la iglesia del Hospital, a razón de cuatro reales por cada misa. Sus cuentas las ha de dar al cabildo; y su salario ha de ser el que el cabildo le señalare.

Constitución $X X X X V$.

De los médicos y cirujano.

Continuamente ha de tener este Hospital dos médicos y un cirujano, que ha de nombrar el administrador de los más acreditados que hubiere en la ciudad, y convendrá sean los que asistieren al hospital de la Misericordia para que faciliten que se reciban en él los enfermos hijos de este Hospital. El uno de los médicos y el cirujano han de asistir a los niños de pecho que enfermaren en la sala, a la ama mayor, a la maestra de las niñas, maestro de los niños y a las dos mujeres 
que cuiden de los muchachos, haciéndolos el médico dos visitas regulares y alguna más, si lo pidiere la enfermedad; y el cirujano sangrándolos cuando se ofreciere y curándolos siempre que tuvieren mal que toque a su facultad: también han de ser obligados a venir, por una vez, siempre que los llamaren para cualquier accidente pronto que ocurriere en los muchachos y muchachas del número, y para informar al administrador de lo que condujere a la curación de cualquiera de los hijos de este Hospital; por el cual trabajo se ha de dar cada año al médico trescientos reales de vellón y al cirujano ciento. El otro médico y el mismo cirujano han de visitar a los niños que se criaren dentro de Toledo, o en sus arrabales, y a los de destete que por pequeños no los reciban en los hospitales de enfermos: para lo cual se ha de observar que en enfermando alguno de ellos, la ama que le criare ha de dar cuenta al administrador; quien informado del mal que la criatura padeciere, y juzgando conveniente que le visite el médico o cirujano, dará para él su cédula, con expresión de la criatura y de la ama que le criare, quien acudirá con la cédula al médico o cirujano: y el que fuere anotará en la misma cédula las visitas que hiciere a la criatura en ella expresada; al fin del año traerán uno y otro al administrador las cédulas con certificación jurada de haber hecho las visitas, que de ellas constare, y les pagará a razón de un real al cirujano, si no es que hiciere sangria, pues entonces se le dará también un real.

Constitución $X X X X \mathrm{X} I$.

De la procesión de los niños en el día de la Natividad de Nuestra Señora.

Cada año en el día de la Natividad de Nuestra Señora por la mañana, han de ir en procesión a la santa iglesia todas las amas, que criaren niños en este Hospital, ya sean de pecho o ya sean de destete: las dos amas de pecho que hubiere en la sala, cada una con su niño, las niñas del número con la maestra, y los muchachos del número con el maestro: asistirá la parroquia de san Nicolás, los dos capellanes del Hospital y el sacristán: antes que salga la procesión, ha de sonar el tambor en la lonja del hospital desde las seis de la mañana: y en dando las siete, para que el repartimiento de las velas se haga con buen orden, el sacristán y el mayordomo harán que se recojan todas las amas dentro de la iglesia, cerrará el mayordomo con llave la puerta que entra desde la portería hasta el primer patio, y el sacristán prevenido con las velas que fuere menester. se pondrá con el mayordomo en la puerta del crucero de la iglesia que sale del pasillo, por donde irán saliendo las amas una a una, y la que llevare el niño y la cédula del folio (que reconocerá el mayordomo y se la volverá) la dará el sacristán una vela de dos onzas: la que también ha de dar a la ama mayor, a la maestra y a las dos amas del pecho de la sala. En acabando de tomar las velas todas las amas, se mantendrán en los tramos del patio hasta que den las ocho, y entretanto repartirá el sacristán velas de a cuarterón a los clérigos de la parroquia, a los dos capellanes del Hospital y al maestro de los muchachos, reservan- 
do una para sí. En dando las ocho, abrirá el mayordomo la puerta que sale del patio a la porteria, para que por alli salgan las amas y el sacristán ordenará la procesión en esta forma: Primero irá el tamborilero tocando, después el pendón del Hospital, al que seguirán la cruz de san Nicolás y la del Hospital; tras de las cruces irán las amas de pecho de la sala con los niños bien adornados de mantillas y dijes (de que cuidará el ama mayor), a las amas de pecho seguirán las niñas del número de dos en dos, presididas de la maestra, y detrás de ella irán los muchachos del número también de dos en dos, asistidos del maestro, luego los dos capellanes del Hospital, y cerrarán la procesión el cura y beneficiados de san Nicolás. Con este orden caminará la procesión por la plaza de Zocodover y la calle Ancha, hasta la puerta del Niño Perdido, adonde esperará a que en el coro acaben de cantar tercia. En acabando, que empiece a sonar el órgano, se encamirá la procesión al coro, entrará en él por la puerta del Evangelio y dándole vuelta saldrá por la puerta del lado de la Epistola; y entretanto que se inciensen las Santas Reliquias, se tenderá por el crucero y nave mayor hacia el altar de Santa Lucía, dejando libre el ámbito entre los dos coros. En esta forma esperará a que se forme la procesión del cabildo, y en empezando a caminar la cruz de la santa iglesia, andará delante de la procesión el cabildo, al mismo patio y por la misma parte. En volviendo al crucero, le atravesará y saldrá por la puerta del Niño Perdido, encaminándose al Hospital por donde vino. En llegando al Hospital, entrarán todas las amas en la iglesia y cerrando el sacristán la reja con la llave, irá a la puerta del Crucero y allí entre él y el mayordomo repartirán una propina de dos reales a cada una de las amas que tuvieren vela; haciendo que salgan una a una, y que conforme vayan saliendo, marchen a sus casas. Este dia, por razón de la procesión, se darán también la propinas siguientes: a la parroquia de San Nicolás ocho reales, y al que lleve el pendón real y medio; al que lleve la cruz dos reales; a los dos muchachos que lleven dos ciriales dos reales; al tamborilero ocho reales, a cada capellán del Hospital cuatro reales; al sacristán cuatro reales; a la ama mayor cuatro reales; a cada ama de pecho de la sala tres reales; a cada ama de pecho de la sala tres reales; a la maestra cuatro reales; al maestro cuatro reales; a la ama de los muchachos y a su asistenta cuatro reales; al portero dos reales; a la barrendera dos reales; al mozo de la casa de los muchachos dos reales; y al dia siguiente se dará un almuerzo caliente, de poca costa, a las niñas de labor y a los muchachos del número. 